OPEN ACCESS

Edited by: David Emerson,

Bigelow Laboratory for Ocean Sciences, USA

Reviewed by: Amy Michele Grunden, North Carolina State University, USA Daniel H. Buckley, Cornell University, USA

${ }^{*}$ Correspondence:

Edith Bai

baie@iae.ac.cn

Specialty section: This article was submitted to Microbiological Chemistry and Geomicrobiology, a section of the journal Frontiers in Microbiology

Received: 23 May 2016 Accepted: 01 July 2016 Published: 13 July 2016

Citation:

Xia Z, Bai E, Wang $Q$, Gao $D$ Zhou J, Jiang P and Wu J (2016) Biogeographic Distribution Patterns of Bacteria in Typical Chinese Forest Soils. Front. Microbiol. 7:1106. doi: 10.3389/fmicb.2016.01106

\section{Biogeographic Distribution Patterns of Bacteria in Typical Chinese Forest Soils}

\author{
Zongwei Xia, Edith Bai*, Qingkui Wang, Decai Gao, Jidong Zhou, Ping Jiang and \\ Jiabing Wu
}

Institute of Applied Ecology, Chinese Academy of Sciences, Shenyang, China

Microbes are widely distributed in soils and play a very important role in nutrient cycling and ecosystem services. To understand the biogeographic distribution of forest soil bacteria, we collected 115 soil samples in typical forest ecosystems across eastern China to investigate their bacterial community compositions using Illumina MiSeq high throughput sequencing based on 16S rRNA. We obtained 4,667,656 sequences totally and more than $70 \%$ of these sequences were classified into five dominant groups, i.e., Actinobacteria, Acidobacteria, Alphaproteobacteria, Verrucomicrobia, and Planctomycetes (relative abundance $>5 \%$ ). The bacterial diversity showed a parabola shape along latitude and the maximum diversity appeared at latitudes between $33.50^{\circ} \mathrm{N}$ and $40^{\circ} \mathrm{N}$, an area characterized by warm-temperate zones and moderate temperature, neutral soil $\mathrm{pH}$ and high substrate availability (soil $\mathrm{C}$ and $\mathrm{N}$ ) from dominant deciduous broad-leaved forests. Pairwise dissimilarity matrix in bacterial community composition showed that bacterial community structure had regional similarity and the latitude of $30^{\circ} \mathrm{N}$ could be used as the dividing line between southern and northern forest soils. Soil properties and climate conditions (MAT and MAP) greatly accounted for the differences in the soil bacterial structure. Among all soil parameters determined, soil pH predominantly affected the diversity and composition of the bacterial community, and soil $\mathrm{pH}=5$ probably could be used as a threshold below which soil bacterial diversity might decline and soil bacterial community structure might change significantly. Moreover, soil exchangeable cations, especially $\mathrm{Ca}^{2+}\left(\mathrm{ECa}^{2+}\right)$ and some other soil variables were also closely related to bacterial community structure. The selected environmental variables $(21.11 \%)$ explained more of the bacterial community variation than geographic distance (15.88\%), indicating that the edaphic properties and environmental factors played a more important role than geographic dispersal limitation in determining the bacterial community structure in Chinese forest soils.

\footnotetext{
Keywords: Chinese forest soil, microbial biogeography, soil bacterial diversity, soil pH, 16S rRNA, high throughput sequencing
}

\section{INTRODUCTION}

Microbes are widely distributed in soils and play a very important role in nutrient cycling and ecosystem services. It is generally recognized that the microbial diversity and composition are key determinants of their ecological functions (Brussaard, 1997). Many studies in the recent decade have shown that soil microbes from various ecosystems exhibit biogeographic distribution 
patterns (Fierer and Jackson, 2006; Ge et al., 2008; Lauber et al., 2009; Chu et al., 2010), which generally differs from the patterns observed for plant and animal taxa (Levin, 1992; Gaston, 2000; Allen et al., 2002). The biogeographic distribution patterns of animals and plants are simultaneously determined by both environmental heterogeneity and geographic dispersal limitation (Ganderton and Coker, 2005; Lomolino et al., 2006), while the biogeographic distribution patterns of soil bacteria is thought to be mainly determined by soil variables and local environment conditions (Garbeva et al., 2004; Ramette and Tiedje, 2007; Green et al., 2008). However, due to the limitations by the technique of high-resolution classification and the difficulties in largescale survey, our understanding of the biogeographic distribution of soil bacterial community remains limited (Martiny et al., 2006).

Previous studies on the biogeographic distribution of bacterial communities indicated that soil bacterial community structure was influenced by edaphic, climatic or land cover characteristics (Cho and Tiedje, 2000; Zhou et al., 2002; Yergeau et al., 2007), and the controlling factors varied at different spatial scales and in different ecosystem types. Dequiedt et al. (2009) reported that the bacterial community composition was more related to soil properties and land cover than to climatic and geomorphologic characteristics in four different regions of France. In contrast, soil bacterial community abundance and structure in arid and semiarid regions were found to be significantly correlated to both precipitations (or expressed as aridity) and soil properties at large spatial scales (Pasternak et al., 2013; Maestre et al., 2015; Wang et al., 2015). Among the soil characteristics, soil $\mathrm{pH}$ was often reported as an overriding factor on determining bacterial communities structure (Fierer and Jackson, 2006; Baker et al., 2009; Liu et al., 2014) and some individual taxonomic groups (Nicol et al., 2008; Davis et al., 2009; Jenkins et al., 2009; Jones et al., 2009). Additionally, other parameters have also been found to influence the composition and diversity of soil bacterial communities, such as soil nutrient availability (Broughton and Gross, 2000; Liu et al., 2010; Naether et al., 2012), salinity (Crump et al., 2004; Lozupone and Knight, 2007), plant diversity and community composition (Stephan et al., 2000; Wardle et al., 2004). Although the same factor may show different levels of influences on bacterial community structure in different ecosystems or at different spatial scales, some common bacteria may exist in many areas. For example, the Verrucomicrobia phylum was detected in almost all soils collected across a range of biomes in North America, South America, Europe, and Antarctica (Bergmann et al., 2011). Therefore, it is important to understand the distribution patterns of main bacterial groups at different spatial scales and at the same time explore the factors determining these patterns.

In contrast to the relatively large number of studies examining soil bacterial community structure across broad spatial ranges in Europe and the Americas, a comprehensive understanding of the biogeographic distribution of soil bacterial community across China is still lacking. Until now, only a few studies have focused on the soil bacterial community structure at a large scale in China (Liu et al., 2014; Wang et al., 2015). In this study, we collected
115 soil samples in forests from north to south China, covering tropical forest, subtropical forest, temperate forest and boreal forest types, and investigated on the spatial variations of these soil bacterial community compositions. Soil bacterial communities were determined based on the data of 16S rRNA sequences (V4 V5 hypervariable region) using Illumina MiSeq. The objectives of this study were: (1) to determine the composition of the soil bacterial community of different forest types across eastern China; (2) to explore the biogeographic distribution patterns of soil bacterial communities across such a wide range; and (3) to examine the dominant factors in shaping the distribution of the bacterial community structure of these soils.

\section{MATERIALS AND METHODS}

\section{Site Selection and Soil Sampling}

We collected 115 mineral soil samples from typical forests with different vegetation types across north and south China with the latitudes ranging from $18.70^{\circ} \mathrm{N}$ to $51.53^{\circ} \mathrm{N}$ (Figure 1). These soil samples harbor a wide range of soil types and edaphic and environmental characteristics (Supplementary Table S1). Mean annual temperature (MAT) and mean annual precipitation (MAP) data in sampling locations were obtained from WorldClim ${ }^{1}$. All samples were taken in July and August, 2014. At each site, eight to ten randomly selected soil cores $(0-10 \mathrm{~cm}, 5 \mathrm{~cm}$ in diameter) were collected within an area of about $400 \mathrm{~m}^{2}$. Soil samples were combined into one composite sample for each site, and then transported at $4^{\circ} \mathrm{C}$ to the Institute of Applied Ecology, Chinese Academy of Sciences at Shenyang, China. Soil samples were sieved through 2-mm mesh to thoroughly homogenize and remove roots, plant detritus and stones. A portion of each soil sample was stored at $-20^{\circ} \mathrm{C}$ until DNA extraction. The remaining soils were used to determine extractable $\mathrm{NH}_{4}^{+}$and $\mathrm{NO}_{3}^{-}$contents, soil microbial biomass carbon (MBC) content and soil physicochemical properties.

\section{Soil Physicochemical Properties}

Soil $\mathrm{pH}$ was measured using a $\mathrm{pH}$ meter in the supernatant after shaking soil - water $(1: 5 \mathrm{w} / \mathrm{v})$ mixture for $30 \mathrm{~min}$. Soil total carbon, total nitrogen were determined using an Elemental analyzer (VarioEL III, Germany), while soil available phosphorus and total phosphorus were determined as previously described methods (Kuo, 1996). Soil $\mathrm{NH}_{4}{ }^{+}$and $\mathrm{NO}_{3}{ }^{-}$were extracted with $2 \mathrm{M}$ KCL solution for $1 \mathrm{~h}$ on a shaker, and their contents were determined using a flow injection analyzer (Futura, Alliance, France). The soil MBC was estimated using the chloroform fumigation-extraction method (Vance et al., 1987; Joergensen, 1996). The soil exchangeable $\mathrm{K}^{+}, \mathrm{Na}^{+}, \mathrm{Ca}^{2+}$, and $\mathrm{Mg}^{2+}$ were determined by extracting the soils with ammonium acetate (Thomas, 1982). Amounts of $\mathrm{Ca}^{2+}$ and $\mathrm{Mg}^{2+}$ in the extracts were analyzed by atomic absorption spectrometry (AAS) and $\mathrm{K}^{+}$and $\mathrm{Na}^{+}$were analyzed by flame photometry.

\footnotetext{
${ }^{1}$ http://www.worldclim.org/
} 


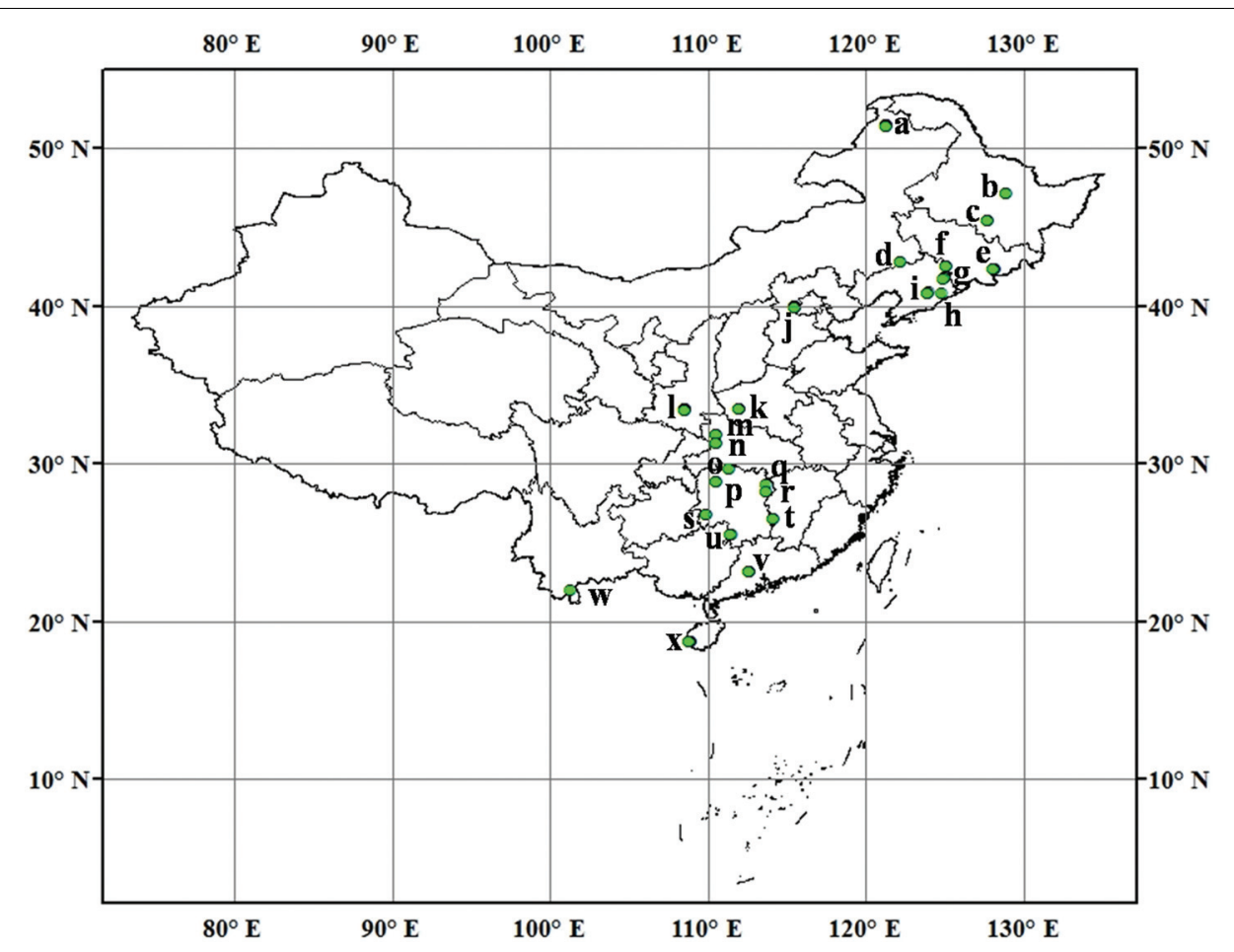

FIGURE 1 | Sampling locations and sample number in each location across North and South of Chinese forest soils. (a) Daxingan, 12; (b) Liangshui, 2; (c) Maoershan, 4; (d) Daqinggou, 2; (e) Changbaishan, 6; (f) Binglashan, 4; (g) Qingyuan, 5; (h) Baishila, 1; (i) Caohekou, 4; (j) Beijing, 12; (k) Baotianman, 9; (I) Qinling, 12; (m) Shennongjia, 3; (n) Huanglianba, 3; (o) Changde, 2; (p) Huaihua, 3; (q) Yueyang, 1; (r) Changsha, 2; (s) Huitong, 3; (t) Zhuzhou, 3; (u) Yongzhou, 3; (v) Dinghushan, 9; (w) Xishuangbanna, 1; (x) Jianfengling, 9.

\section{Soil DNA Extraction}

Each soil DNA was extracted from the $0.25 \mathrm{~g}$ freeze-dried soil after sampling using a Mobio PowerSoil DNA Isolation Kit (MoBio Laboratories, Carlsbad, CA, USA) according to the manufacturer's instructions. DNA was eluted with $100 \mu \mathrm{l}$ Tris buffer $(10 \mathrm{mM})$, quantified by spectrophotometer at $260 \mathrm{~nm}$ and stored at $-20^{\circ} \mathrm{C}$ until use.

\section{Bacterial 16S rRNA Amplicon and Barcoded Sequencing}

Soil DNA samples were sent to Novogene Company (Beijing, China) for high-throughput sequencing. The amplicon targeting V4-V5 hypervariable region of bacterial 16S rRNA was amplified with primer set 515F/806R, which contained sample specific 6bp barcodes in the $5^{\prime}$ ends of them. The sequences of $515 \mathrm{~F}$ and 806R were $5^{\prime}$ - NNN NNN (barcode) GTG CCA GCM GCC GCG GTA A $-3^{\prime}$ and $5^{\prime}-$ NNN NNN (barcode) GGA CTA CHV GGG TWT CTA AT $-3^{\prime}$, respectively. All PCR reactions were carried out in a volume of $30 \mu \mathrm{l}$ mixture containing $15 \mu \mathrm{l}$ of Phusion ${ }^{\circledR}$ High-Fidelity PCR Master Mix (New England Biolabs), $0.2 \mu \mathrm{M}$ of each primer, about $10 \mathrm{ng}$ template DNA, and $\mathrm{ddH}_{2} \mathrm{O}$ filled to $30 \mu \mathrm{l}$. Thermal cycling included an initial denaturation at $98^{\circ} \mathrm{C}$ for $1 \mathrm{~min}$, followed by 30 cycles of denaturation at $98^{\circ} \mathrm{C}$ for $10 \mathrm{~s}$, annealing at $50^{\circ} \mathrm{C}$ for $30 \mathrm{~s}$, and elongation at $72^{\circ} \mathrm{C}$ for $1 \mathrm{~min}$, with a final extension at $72^{\circ} \mathrm{C}$ for $5 \mathrm{~min}$. PCR products were detected by $2 \%$ agarose gel electrophoresis, and those with bright main strip between 400 and 450 bp were chosen for further experiments. Equal amounts of the PCR product from each sample were pooled and then purified with GeneJET Gel Extraction Kit (Thermo Scientific). The sequencing library was generated using NEB Next ${ }^{\circledR}$ Ultra ${ }^{\mathrm{TM}}$ DNA Library Prep Kit for Illumina (NEB, USA) following the manufacturer's instructions and thus sequencing adapters were added to $5^{\prime}$ ends of amplicon. The library quality was assessed on the Qubit ${ }^{@} 2.0$ Fluorometer (Thermo Scientific) and Agilent Bioanalyzer 2100 system. At last, the qualified library was sequenced on the Illumina MiSeq platform, producing $250 \mathrm{bp} / 300 \mathrm{bp}$ paired-end reads.

\section{Processing of Sequencing Data}

Paired-end reads from the original amplicon were merged using FLASH (Magoč and Salzberg, 2011) which is designed to merge paired-end reads when there are overlaps between reads1 and reads2. Paired-end reads was assigned to each sample according to the unique barcodes which were removed together with primers subsequently. Sequences were analyzed using QIIME software package (Quantitative Insights Into Microbial Ecology ${ }^{2}$ ) (Caporaso et al., 2010), and in-house Perl scripts were used to analyze alpha-(within samples) and beta-(among samples) diversity. First, merged reads were filtered by QIIME quality filters. Then the clean sequences obtained with $\geq 97 \%$ similarity level were assigned to the same operational taxonomic

\footnotetext{
${ }^{2} \mathrm{http}: / /$ qiime.org/
} 
units (OTUs). A representative sequence from each OTU was picked and annotated using the RDP classifier for taxonomic information (Wang et al., 2007) and aligned with "Core Set" in the GreenGene database for phylogenetic information (DeSantis et al., 2006). In order to unify the survey (Shaw et al., 2008), a subsample of randomly selected 7300 sequences in each sample was used for bacterial alpha-diversity (phylotype richness and phylogenetic diversity) and beta-diversity (community dissimilarity index) analyses. Observed Species and Phylogenetic Diversity Whole Tree (PD for short) indexes formed during alpha-diversity analysis were used to indicate phylotype richness and phylogenetic diversity in samples, respectively. Unifrac metric was used to compare the difference of overall community composition between each pair of samples (Lozupone and Knight, 2005), and thus generating unweighted and weighted pairwise unifrac distance matrixes. All sequences in this study are available in Sequence Read Achieve (SRA) database of NCBI under accession number SRP070864.

\section{Statistic Analyses}

Correlation (Pearson's rank correlation) or regression analysis between soil/site characteristics and individual phyla or between soil/site characteristics and indexes of community diversity and composition were performed in SPSS 17.0 for Windows. The other statistical analyses were conducted using the program $\mathrm{R}$ v.3.2.0 (R Development Core Team, 2006). The "Bray-Curtis" dissimilarity matrix for the bacterial community composition and the "Euclidean" dissimilarity matrices for geographic distance and environmental variables were constructed with the "vegdis" "function in the "vegan" package (Oksanen et al., 2016). The non-metric multidimensional scaling (NMDS) and cluster analysis of soil samples in the bacterial community composition was conducted with the "metaMDS" (Minchin, 1987) and "hclust" functions (Murtagh, 1985) based on the "Bray-Curtis" dissimilarity matrix within the package "vegan," respectively. Additionally, we conducted 1 minus Unifrac distance (unweighted or weighted) in the total community structure to estimate the bacterial community similarity. BioEnv procedure (Clarke and Ainsworth, 1993) was performed to select the environmental variables which were further used to construct environmental distance matrix with the "vegdist" function. Using principle coordinates of neighbor matrices (PCNM) method (Borcard and Legendre, 2002), the geographic coordinates of the sites were transformed to significant vectors that could be used to construct geographic distance matrix across sites. Mantel tests with 999 permutations (Legendre and Legendre, 2012) were used to examine the correlation (Pearson's rank correlation) between geographic or environmental distance and bacterial community distance within the vegan package. The canonical correspondence analysis (CCA) (Legendre and Legendre, 2012) was employed to identify the most important soil environmental factors shaping bacterial community structure. Monte Carlo permutation test (permutest) and "envfit" functions (Legendre et al., 2011) were used to test the significant environmental variables during CCA analysis. These significant PCNM vectors and environmental variables were used as explanatory variables in constrained ordinations (CCA) for variation partition analysis.

\section{RESULTS}

\section{Soil and Site Characteristics}

The latitude of each sampling site was highly correlated with the site's MAT $(r=-0.982, P<0.001)$ and MAP $(r=-0.873$, $P<0.001$ ) (Table 1). Soil $\mathrm{pH}$ showed significant correlations with concentrations of three types of exchangeable cations, i.e., $\mathrm{K}^{+}(r=0.685, P<0.001), \mathrm{Ca}^{2+}(r=0.843, P<0.001)$, $\mathrm{Mg}^{2+}(r=0.776, P<0.001)$. Soil $\mathrm{pH}$ and these three cations increased with increasing latitude (Table 1). Soil total C (TC) was significantly positively correlated with soil total $\mathrm{N}$ (TN) ( $r=0.733, P<0.001)$, and they both were correlated with soil $\mathrm{pH}$ and these three cations. The latitudes of sampling sites were not significantly correlated with $\mathrm{TC}, \mathrm{TN}$, soil $\mathrm{NH}_{4}^{+}$or $\mathrm{NO}_{3}^{-}$contents. Soil $\mathrm{NH}_{4}^{+}$and $\mathrm{NO}_{3}^{-}$contents were significantly correlated with soil $\mathrm{pH}$ and $\mathrm{TC}, \mathrm{TN}$, exchangeable $\mathrm{Ca}^{2+}$ and exchangeable $\mathrm{Mg}^{2+}$ contents. Soil MBC had no significant relationship with other soil and site characteristics except for soil $\mathrm{NH}_{4}^{+}$(Table 1).

\section{Distribution and Abundance of Soil Bacterial Taxa}

We obtained 4,667,656 sequences from all 115 samples, with an average of 40,588 sequences per sample. The range of sequences per sample in the whole dataset was from 7317 to 190250, and most samples (80\%) had sequences between 16000 and 65000 (12 samples had less than 16000 sequences and 11 samples had more than 65000 sequences). The length of these sequences ranged of 191-351 bp, with a mean of $253 \mathrm{bp}$. Among these sequences, $98.6 \%$ could be classified. At the $97 \%$ similarity level, the sequences in all soils could be grouped into 325,433 phylotypes, with an average of 2,830 phylotypes per sample. Actinobacteria, Acidobacteria, Alphaproteobacteria, Verrucomicrobia and Planctomycetes (relative abundance $>5 \%$ ) were dominant groups across all sequence data, and they accounted for more than $73 \%$ of the bacterial sequences (Supplementary Table S2). Moreover, groups of Chloroflexi, Betaproteobacteria, Deltaproteobacteria, Gammaproteobacteria, Gemmatimonadetes, Nitrospirae, Bacteroidetes and AD3 (relative abundance $>1 \%$ ) were less abundant (accounting for $22 \%$ of the bacterial sequences), but still existed in all soils. The rest of sequences could be classified into 56 groups, and 40 groups were rare (relative abundance $<0.01 \%$ ) (Supplementary Table S2).

\section{Dominant Bacterial Groups and Their Relationships with Soil/Site Properties}

The abundance of some dominant bacterial groups was significantly correlated with soil and site characteristics (Table 2). The abundance of Verrucomicrobia $(r=0.472, P<0.001$; $r=0.511, P<0.001)$, Gemmatimonadetes $(r=0.628, P<0.001$; $r=0.328, P<0.001)$ and Armatimonadetes $(r=0.409$, $P<0.001 ; r=0.464, P<0.001)$ increased with increasing geographic latitude; while the abundance of Alphaproteobacteria $(r=-0.429, P<0.001 ; r=-0.331, P<0.001)$ and Gammaproteobacteria $(r=-0.601, P<0.001 ; r=-0.523$, $P<0.001)$ decreased with increasing geographic latitude 
TABLE 1 | The correlation matrix between soil/site properties.

\begin{tabular}{|c|c|c|c|c|c|c|c|c|c|c|c|c|c|c|c|}
\hline & & Latitude & MAT & MAP & $\mathrm{pH}$ & $\mathrm{ENa}$ & EK & $\mathrm{ECa}$ & EMg & TC & TN & TP & AP & $\mathrm{NH}_{4}^{+}$ & $\mathrm{NO}_{3}^{-}$ \\
\hline \multirow[t]{2}{*}{ MAT } & $r$ & -0.982 & & & & & & & & & & & & & \\
\hline & $P$ & 0.000 & & & & & & & & & & & & & \\
\hline \multirow[t]{2}{*}{ MAP } & $r$ & -0.873 & 0.846 & & & & & & & & & & & & \\
\hline & $P$ & 0.000 & 0.000 & & & & & & & & & & & & \\
\hline \multirow[t]{2}{*}{$\mathrm{pH}$} & $r$ & 0.418 & -0.434 & -0.593 & & & & & & & & & & & \\
\hline & $P$ & 0.000 & 0.000 & 0.000 & & & & & & & & & & & \\
\hline \multirow[t]{2}{*}{$\mathrm{ENa}$} & $r$ & -0.122 & 0.177 & -0.010 & 0.030 & & & & & & & & & & \\
\hline & $P$ & 0.193 & 0.058 & 0.915 & 0.753 & & & & & & & & & & \\
\hline \multirow[t]{2}{*}{ EK } & $r$ & 0.333 & -0.359 & -0.476 & 0.685 & 0.112 & & & & & & & & & \\
\hline & $P$ & 0.000 & 0.000 & 0.000 & 0.000 & 0.235 & & & & & & & & & \\
\hline \multirow[t]{2}{*}{ ECa } & $r$ & 0.465 & -0.484 & -0.560 & 0.843 & -0.023 & 0.668 & & & & & & & & \\
\hline & $P$ & 0.000 & 0.000 & 0.000 & 0.000 & 0.807 & 0.000 & & & & & & & & \\
\hline \multirow[t]{2}{*}{ EMg } & $r$ & 0.506 & -0.524 & -0.569 & 0.776 & -0.115 & 0.610 & 0.886 & & & & & & & \\
\hline & $P$ & 0.000 & 0.000 & 0.000 & 0.000 & 0.222 & 0.000 & 0.000 & & & & & & & \\
\hline \multirow[t]{2}{*}{ TC } & $r$ & 0.092 & -0.125 & -0.120 & 0.358 & -0.082 & 0.331 & 0.651 & 0.612 & & & & & & \\
\hline & $P$ & 0.330 & 0.181 & 0.200 & 0.000 & 0.386 & 0.000 & 0.000 & 0.000 & & & & & & \\
\hline \multirow[t]{2}{*}{$\mathrm{TN}$} & $r$ & 0.090 & -0.100 & -0.122 & 0.382 & -0.013 & 0.311 & 0.575 & 0.605 & 0.733 & & & & & \\
\hline & $P$ & 0.339 & 0.287 & 0.194 & 0.000 & 0.890 & 0.001 & 0.000 & 0.000 & 0.000 & & & & & \\
\hline \multirow[t]{2}{*}{ TP } & $r$ & 0.226 & -0.278 & -0.173 & 0.471 & -0.216 & 0.272 & 0.606 & 0.554 & 0.517 & 0.372 & & & & \\
\hline & $P$ & 0.015 & 0.003 & 0.065 & 0.000 & 0.021 & 0.003 & 0.000 & 0.000 & 0.000 & 0.000 & & & & \\
\hline \multirow[t]{2}{*}{$A P$} & $r$ & 0.372 & -0.412 & -0.249 & 0.234 & -0.284 & 0.326 & 0.310 & 0.345 & 0.213 & 0.095 & 0.638 & & & \\
\hline & $P$ & 0.000 & 0.000 & 0.007 & 0.012 & 0.002 & 0.000 & 0.001 & 0.000 & 0.022 & 0.315 & 0.000 & & & \\
\hline \multirow[t]{2}{*}{$\mathrm{NH}_{4}^{+}$} & $r$ & -0.214 & 0.156 & 0.100 & 0.267 & -0.293 & 0.175 & 0.336 & 0.403 & 0.583 & 0.554 & 0.219 & -0.032 & & \\
\hline & $P$ & 0.021 & 0.097 & 0.289 & 0.004 & 0.001 & 0.062 & 0.000 & 0.000 & 0.000 & 0.000 & 0.019 & 0.733 & & \\
\hline \multirow[t]{2}{*}{$\mathrm{NO}_{3}^{-}$} & $r$ & -0.099 & 0.074 & 0.043 & 0.500 & -0.155 & 0.291 & 0.603 & 0.638 & 0.709 & 0.628 & 0.568 & 0.204 & 0.560 & \\
\hline & $P$ & 0.295 & 0.434 & 0.647 & 0.000 & 0.098 & 0.002 & 0.000 & 0.000 & 0.000 & 0.000 & 0.000 & 0.028 & 0.000 & \\
\hline \multirow[t]{2}{*}{$\mathrm{MBC}$} & $r$ & -0.121 & 0.104 & 0.089 & -0.169 & -0.114 & 0.002 & -0.070 & -0.085 & 0.218 & 0.139 & -0.096 & -0.144 & 0.269 & 0.041 \\
\hline & $P$ & 0.197 & 0.269 & 0.345 & 0.072 & 0.226 & 0.982 & 0.456 & 0.366 & 0.019 & 0.139 & 0.309 & 0.124 & 0.004 & 0.660 \\
\hline
\end{tabular}

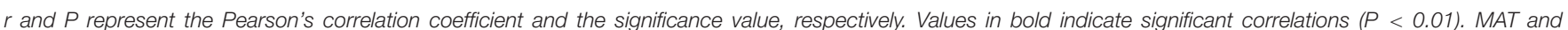

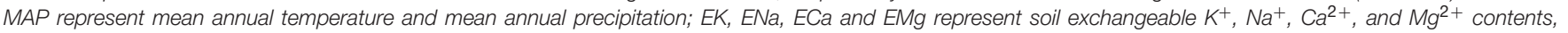

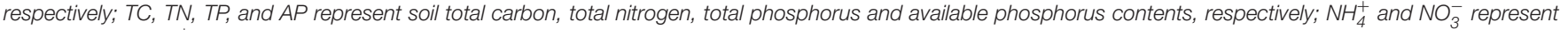
soil extractable $\mathrm{NH}_{4}^{+}$and $\mathrm{NO}_{3}^{-}$levels; $\mathrm{MBC}$ represents soil microbial biomass carbon.

(Table 2). These five bacterial groups were also closely related to MAT and MAP of their locations (Table 2).

Soil $\mathrm{pH}$ and exchangeable $\mathrm{K}^{+}, \mathrm{Ca}^{2+}$, and $\mathrm{Mg}^{2+}$ contents affected many bacterial groups. For example, the relative abundance of Chloroflexi, Betaproteobacteria, Deltaproteobacteria, Gemmatimonadetes, Nitrospirae and Bacteroidetes was positively correlated with soil $\mathrm{pH}$ and exchangeable $\mathrm{K}^{+}, \mathrm{Ca}^{2+}$, and $\mathrm{Mg}^{2+}$ contents, while the relative abundance of Alphaproteobacteria was negatively correlated with these parameters (Table 2; Figures 2 and 3). Although the Acidobacteria group did not show correlation with soil $\mathrm{pH}$ and exchangeable $\mathrm{K}^{+}, \mathrm{Ca}^{2+}$, and $\mathrm{Mg}^{2+}$ contents, most of Acidobacteria subgroups had significant correlations with these parameters (Supplementary Table S3; Supplementary Figures S1 and S2).

Soil total carbon, nitrogen and phosphorus were important factors for some bacterial groups. For example, these three parameters were all positively correlated with the relative abundance of Nitrospirae and Bacteroidetes (Table 2; Supplementary Figures S3 and S4). The relative abundance of Deltaproteobacteria and Gammaproteobacteria showed positive correlations with $\mathrm{TC}$ and $\mathrm{TN}$, while the abundance of Actinobacteria and Firmicutes showed negative correlations with TC and TN. In addition, the relative abundance of Alphaproteobacteria was only correlated with TP but not with TC and TN.

Soil available phosphorus (AP) and extractable $\mathrm{NH}_{4}^{+}$and $\mathrm{NO}_{3}^{-}$contents are nutrients directly used by microbes and therefore were related to many bacterial groups. Soil AP was positively correlated with Bacteroidetes but negatively correlated with Alphaproteobacteria. The relative abundance of Actinobacterial, Betaproteobacteria, Deltaproteobacteria, Gammaproteobacteria, Nitrospirae and Bacteroidetes had significantly positive relationship with soil extractable $\mathrm{NH}_{4}^{+}$and $\mathrm{NO}_{3}^{-}$contents. Soil MBC was only correlated with the relative abundance of Gemmatimonadetes group.

\section{Soil Bacterial Community Diversity}

The pairwise correlation analysis between the indices of the soil bacterial community diversity and soil location, or soil physical and chemical properties showed that soil $\mathrm{pH}, \mathrm{TC}$ and exchangeable $\mathrm{K}^{+}, \mathrm{Ca}^{2+}$, and $\mathrm{Mg}^{2+}$ and extractable $\mathrm{NH}_{4}^{+}$and 


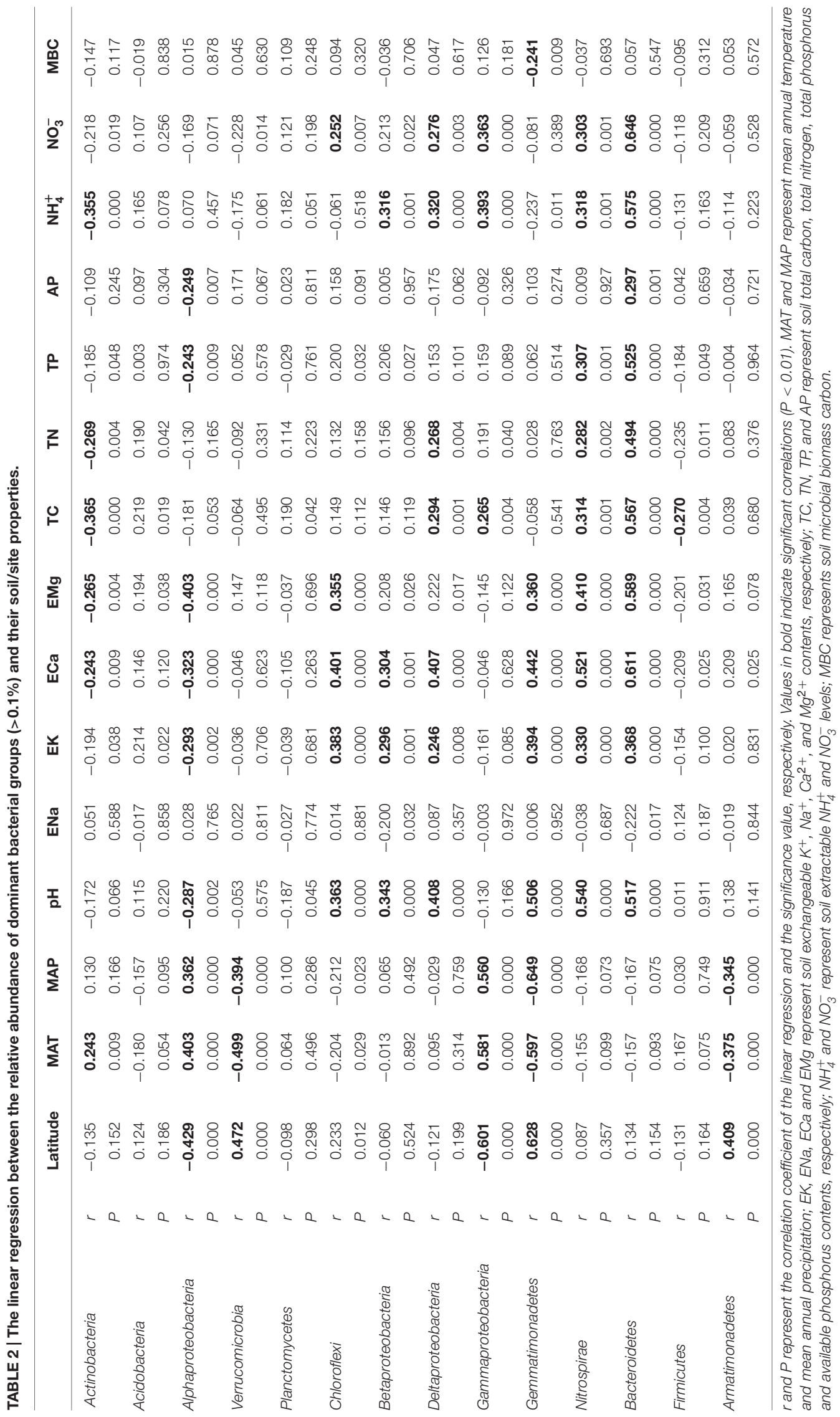



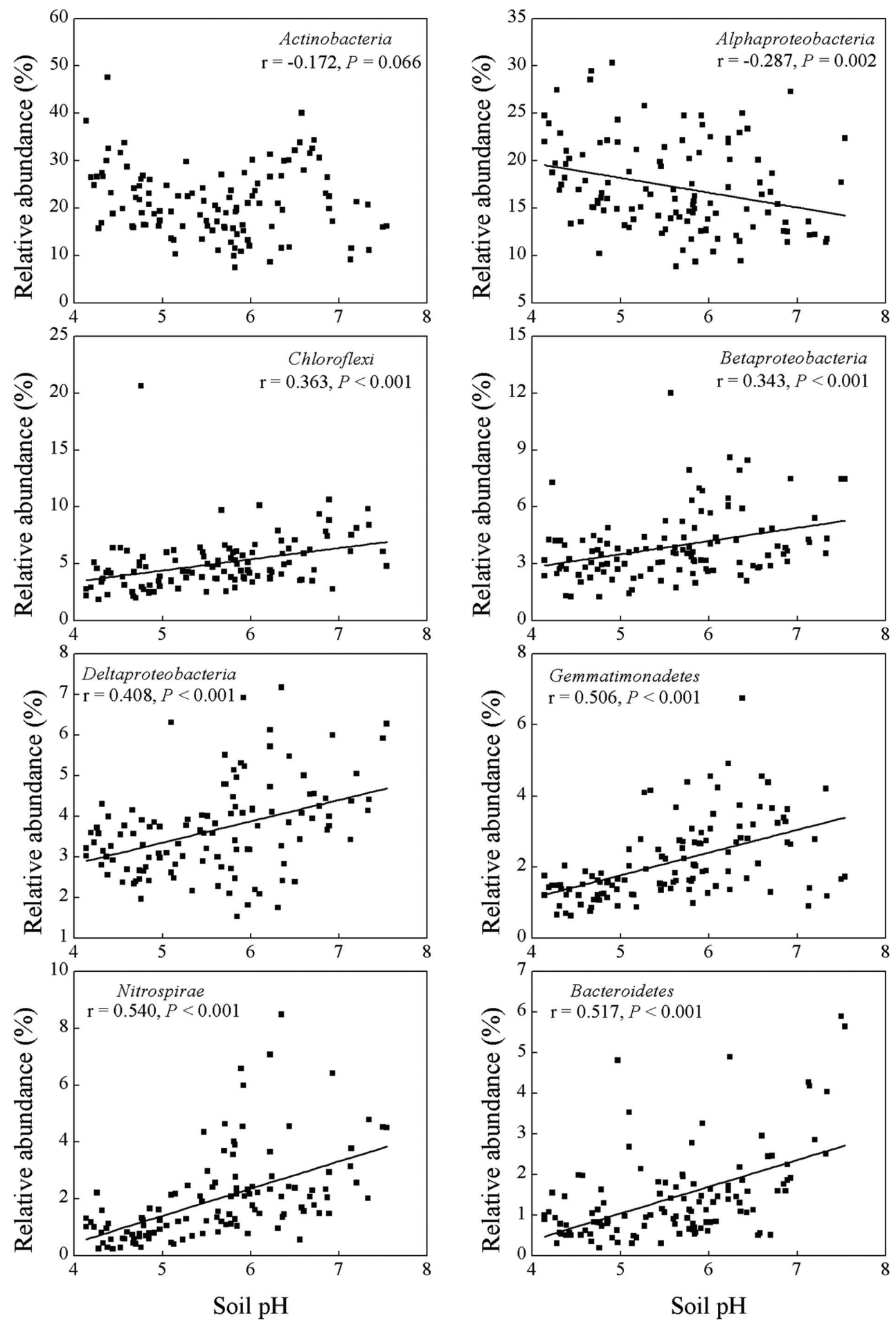

FIGURE 2 | Relationships between the relative abundance of dominant bacterial groups and soil pH.

$\mathrm{NO}_{3}^{-}$contents were significantly positively correlated with both phylotype richness and phylogenetic diversity (Table 3; Figure 4). Soil TN was positively correlated with phylogenetic diversity. A parabolic relationship was found between MAT and bacterial phylotype richness, and between MAT and phylogenetic diversity (Figure 4). Latitude presented similar effects on these indices of the soil bacterial community diversity with the tipping point at between $33.5^{\circ} \mathrm{N}$ and $40^{\circ} \mathrm{N}$. 

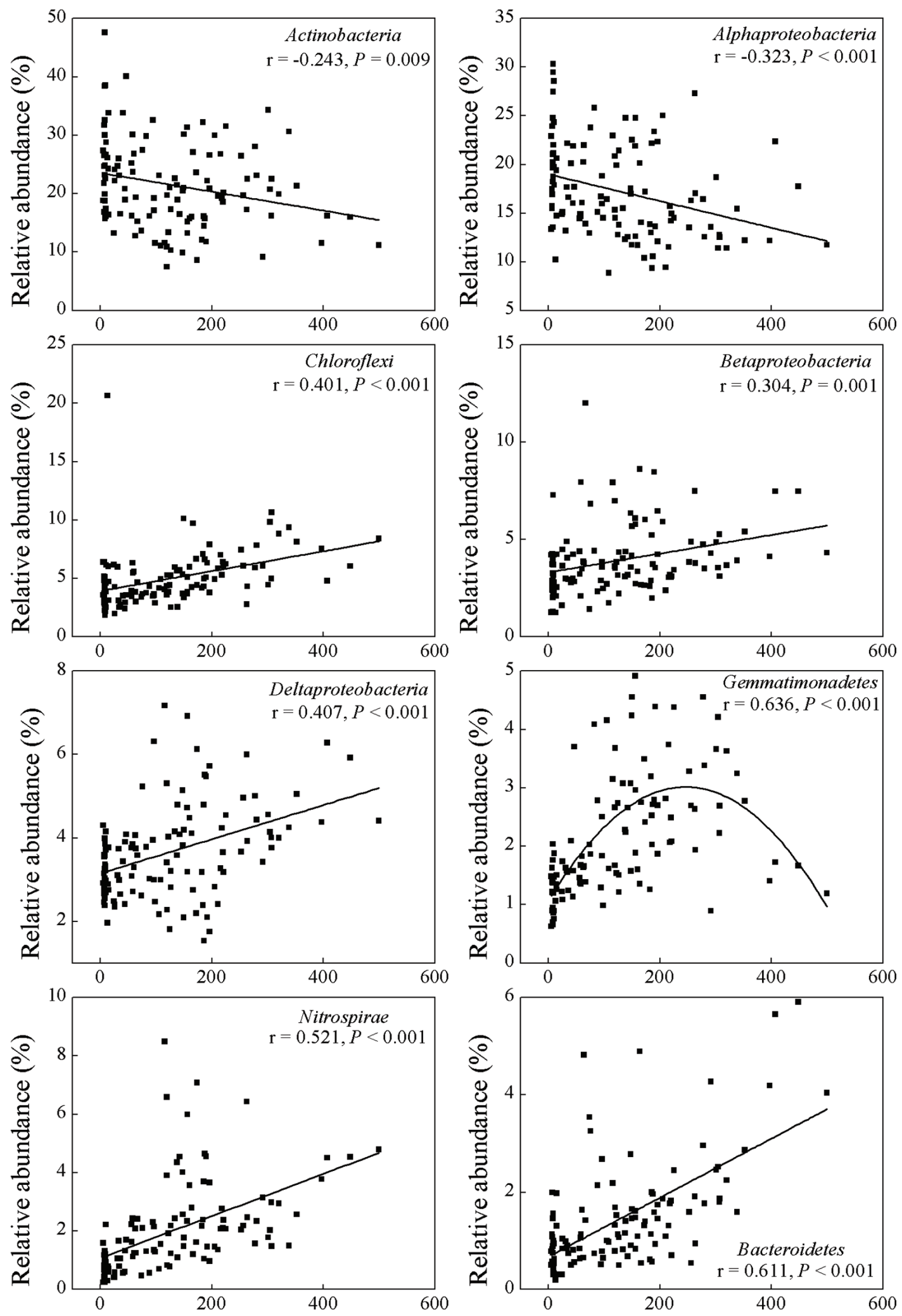

Exchangable $\mathrm{Ca}^{2+}\left(\mathrm{nmol} \mathrm{Kg}{ }^{-1}\left(1 / 2 \mathrm{Ca}^{2+}\right)\right)$ Exchangable $\mathrm{Ca}^{2+}\left(\mathrm{nmol} \mathrm{Kg}{ }^{-1}\left(1 / 2 \mathrm{Ca}^{2+}\right)\right)$

FIGURE 3 | Relationships between the relative abundance of dominant bacterial groups and soil exchangeable $\mathrm{Ca}^{2+}$ content. 
TABLE 3 | The pairwise correlation analysis between soil bacterial diversity indices (phylotypes and phylogenetic diversity, PD for short) and soil location, physical and chemical properties.

\begin{tabular}{|c|c|c|c|c|c|c|c|c|c|c|c|c|c|c|c|c|}
\hline & & Latitude & MAT & MAP & $\mathrm{pH}$ & ENa & EK & $\mathrm{ECa}$ & EMg & TC & TN & TP & AP & $\mathrm{NH}_{4}^{+}$ & $\mathrm{NO}_{3}^{-}$ & MBC \\
\hline \multirow[t]{2}{*}{ Phylotypes } & $r$ & -0.112 & 0.115 & 0.038 & 0.348 & -0.007 & 0.391 & 0.365 & 0.210 & 0.213 & 0.161 & 0.096 & -0.095 & 0.261 & 0.260 & 0.020 \\
\hline & $P$ & 0.232 & 0.220 & 0.684 & 0.000 & 0.939 & 0.000 & 0.000 & 0.024 & 0.022 & 0.086 & 0.305 & 0.314 & 0.005 & 0.005 & 0.836 \\
\hline \multirow[t]{2}{*}{ PD } & $r$ & -0.008 & 0.014 & -0.071 & 0.391 & 0.025 & 0.422 & 0.424 & 0.301 & 0.255 & 0.226 & 0.070 & -0.105 & 0.261 & 0.260 & 0.029 \\
\hline & $P$ & 0.929 & 0.884 & 0.448 & 0.000 & 0.791 & 0.000 & 0.000 & 0.001 & 0.006 & 0.015 & 0.454 & 0.262 & 0.005 & 0.005 & 0.759 \\
\hline
\end{tabular}

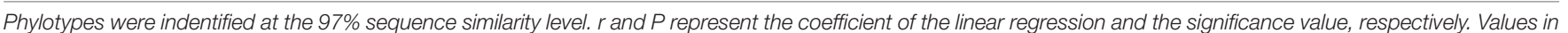

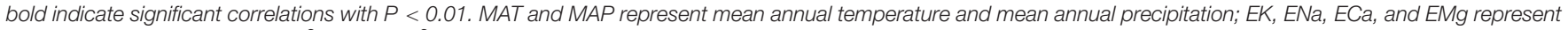

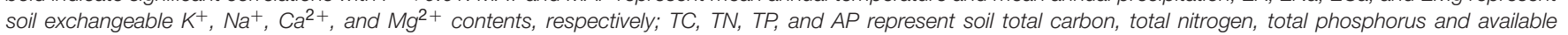
phosphorus contents, respectively; $\mathrm{NH}_{4}^{+}$and $\mathrm{NO}_{3}^{-}$represent soil extractable $\mathrm{NH}_{4}^{+}$and $\mathrm{NO}_{3}^{-}$levels; MBC represents soil microbial biomass carbon.

\section{Soil Bacterial Community Composition}

Mantel test showed that "Bray-Curtis" distances of bacterial community composition was positively correlated with geographic distances $(r=0.259, P<0.001$, Table 4). Except for soil available phosphorus and $\mathrm{MBC}$, all other examined environmental variables presented significant correlations with soil microbial community composition (Table 4). Soil $\mathrm{pH}$ was most strongly correlated with bacterial community composition $(r=0.700, P<0.001)$. Utilization of both soil $\mathrm{pH}$ and soil TN predicted bacterial community composition better $(r=0.708, P<0.001)$, while the addition of the other factors did not improve the regression's efficiency. Moreover, NMDS visualization showed that variation in bacterial community composition was associated with variation in soil $\mathrm{pH}$ and differences in geographic region (Figure 5). Similarly, the significantly linear relationship between NMDS1 of NMDS scores and soil $\mathrm{pH}$ confirmed the importance of soil $\mathrm{pH}$ (Figure 6A). Soil exchangeable $\mathrm{Ca}^{2+}$ content had similar effects on soil bacterial community composition to soil pH (Figure 6B). Additionally, both NMDS1 and NMDS2 scores were closely correlated with MAT and MAP (Figures 6C-F). CCA analysis showed that soil $\mathrm{pH}$, exchangeable $\mathrm{Ca}^{2+}$ and $\mathrm{Mg}^{2+}$, soil $\mathrm{NO}_{3}^{-}$, and MAT and MAP of soil locations were important factors on soil bacterial community composition (Supplementary Figure S6). The directions of $\mathrm{pH}$, exchangeable $\mathrm{Ca}^{2+}$ and $\mathrm{Mg}^{2+}$ were closely correlated with CCA1, while the directions of soil $\mathrm{NO}_{3}^{-}$, MAT and MAP were correlated with both CCA1 and CCA2.

Based on the "Bray-Curtis" dissimilarity matrix, the bacterial communities of the 115 soils were roughly clustered into two big groups (Figure 7). Group I consisted of 32 samples which were mainly from southern forests of China with low latitudes (ranging from $18.70^{\circ} \mathrm{N}$ to $29.65^{\circ} \mathrm{N}$ ). Group II was composed of 83 soils which were located in forests of northern China with middle latitudes ranging from $31.30^{\circ} \mathrm{N}$ to $51.53^{\circ} \mathrm{N}$. Group II could be further divided into two subgroups (A and B). Subgroup A was consisted of 56 soils, most of which were sampled from northeastern China. Subgroup B contained 27 soils, which were sampled from Beijing, Qinling and Shennongjia with the latitude ranging from $31.30^{\circ} \mathrm{N}$ to $39.96^{\circ} \mathrm{N}$ (intermediate zone). These results corresponded to the results of NMDS analysis (Figure 5), which showed that bacterial community structure differed greatly between forest soils with acidic $\mathrm{pH}$ at lower latitude sites (less than $30^{\circ} \mathrm{N}$ ) and forest soils with near-neutral, neutral or weakly alkaline $\mathrm{pH}$ at mid latitude $\left(31^{\circ} \mathrm{N}-40^{\circ} \mathrm{N}\right)$ and high latitude sites $\left(41^{\circ} \mathrm{N}-52^{\circ} \mathrm{N}\right)$ in China. Additionally, the relationship between geographic distances, environmental distance and bacterial community similarity in community composition (Figure 8) indicated that more distinct bacterial communities could be found in two soils far from each other than in two soils with a near distance and also in two soils with more different soil properties.

The variance partitioning analysis showed the relative contributions of the geographic distance and environmental variables to the bacterial community structure (Figure 9). CCA analysis selected a subset of environmental variables (MAT, MAP, pH, TP, EK, ECa, EMg, TC, TN, $\mathrm{NH}_{4}^{+}$and $\mathrm{NO}_{3}^{-}$) which together explained $21.11 \%$ of the bacterial community variation, more than the geographic distance $(15.88 \%)$ (Figure 9). Therefore, the soil characteristics and environmental factors were more important than the geographic dispersal limitation in determining the bacterial community structure in Chinese forest soils. These selected environmental variables, i.e., MAT, MAP, $\mathrm{pH}, \mathrm{TP}, \mathrm{EK}, \mathrm{ECa}$, EMg, TC, TN, $\mathrm{NH}_{4}^{+}$and $\mathrm{NO}_{3}^{-}$, explained 1.86, 2.29, 3.05, 1.33, $1.91,2.85,2.48,1.19,1.04,1.04$, and $2.07 \%$ of the bacterial community variation, respectively. These environmental variables combining geographic distance explained $30.16 \%$ of the bacterial community variation, leaving $69.84 \%$ of unexplained variation, indicating that the overlapping effect of environmental variables and geographic distance on the bacterial community variation was $6.83 \%$ (Figure 9), and that there were many unmeasured or unknown factors that contributed to the large portion of unexplained variation in this study.

\section{DISCUSSION}

\section{Abundance of Dominant Bacterial Communities and Its Relationship with Climatic and Soil Factors}

We found Actinobacteria phylum was the most dominant group $(22 \%)$ in our studied forest soils. Acidobacteria accounted for $18 \%$ of all bacterial communities, while the relative abundance of Bacteroidetes was only about $1.4 \%$. These results only partly agree with findings in the 88 soils across North and South America 

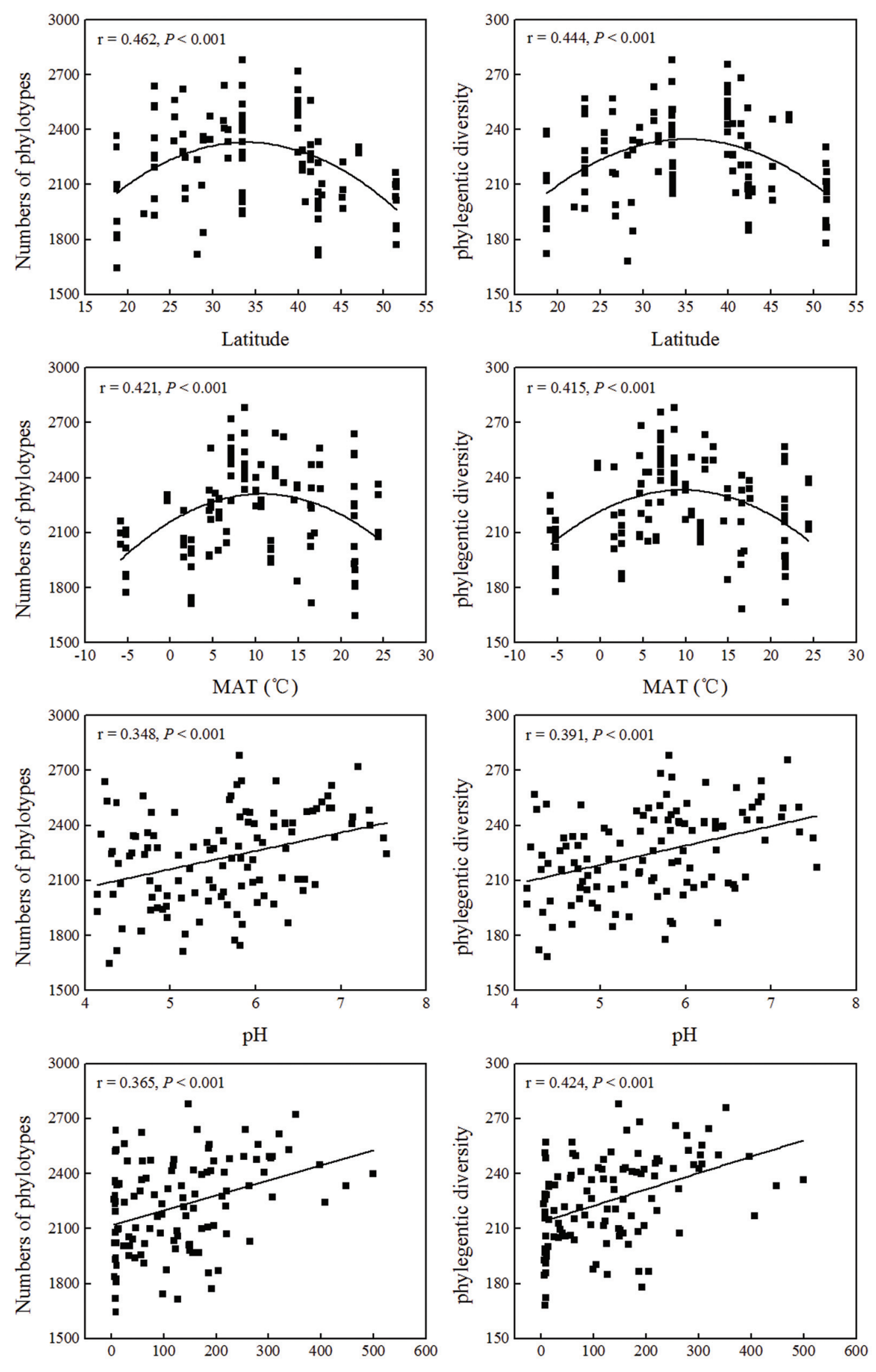

Exchangable $\mathrm{Ca}^{2+}\left(\mathrm{nmol} \mathrm{Kg}{ }^{-1}\left(1 / 2 \mathrm{Ca}^{2+}\right)\right)$

Exchangable $\mathrm{Ca}^{2+}\left(\mathrm{nmol} \mathrm{Kg}{ }^{-1}\left(1 / 2 \mathrm{Ca}^{2+}\right)\right)$

FIGURE 4 | Relationship between soil bacterial diversity indices (phylotypes and phylogenetic diversity) and soil location, or soil physical and chemical properties. 
TABLE 4 | Correlations between "Bray-Curtis" distance of bacterial community composition and geographic or environmental variables distance using Mantel test.

\begin{tabular}{|c|c|c|}
\hline Variable & $r$ & $P$ \\
\hline Geographic distance & 0.259 & 0.001 \\
\hline $\mathrm{pH}$ & 0.700 & 0.001 \\
\hline ECa & 0.626 & 0.001 \\
\hline EMg & 0.535 & 0.001 \\
\hline EK & 0.394 & 0.001 \\
\hline $\mathrm{ENa}$ & 0.151 & 0.003 \\
\hline MAT & 0.257 & 0.001 \\
\hline MAP & 0.415 & 0.001 \\
\hline TC & 0.317 & 0.001 \\
\hline TN & 0.344 & 0.001 \\
\hline TP & 0.268 & 0.001 \\
\hline $\mathrm{NH}_{4}{ }^{+}$ & 0.233 & 0.001 \\
\hline $\mathrm{NO}_{3}{ }^{-}$ & 0.392 & 0.001 \\
\hline AP & 0.081 & 0.131 \\
\hline $\mathrm{MBC}$ & 0.055 & 0.240 \\
\hline $\mathrm{pH}+\mathrm{ECa}$ & 0.626 & 0.001 \\
\hline $\mathrm{pH}+\mathrm{MAT}$ & 0.270 & 0.001 \\
\hline $\mathrm{pH}+\mathrm{MAP}$ & 0.415 & 0.001 \\
\hline $\mathrm{pH}+\mathrm{TC}$ & 0.430 & 0.001 \\
\hline $\mathrm{pH}+\mathrm{TN}$ & 0.708 & 0.001 \\
\hline $\mathrm{pH}+\mathrm{TP}$ & 0.268 & 0.001 \\
\hline $\mathrm{pH}+\mathrm{NH}_{4}^{+}$ & 0.240 & 0.001 \\
\hline $\mathrm{pH}+\mathrm{NO}_{3}^{-}$ & 0.398 & 0.001 \\
\hline $\mathrm{pH}+\mathrm{ECa}+\mathrm{EMg}+\mathrm{EK}$ & 0.628 & 0.001 \\
\hline $\mathrm{pH}+\mathrm{MAT}+\mathrm{MAP}$ & 0.415 & 0.001 \\
\hline $\mathrm{pH}+\mathrm{TC}+\mathrm{TN}$ & 0.431 & 0.001 \\
\hline $\mathrm{pH}+\mathrm{NH}_{4}^{+}+\mathrm{NO}_{3}^{-}$ & 0.358 & 0.001 \\
\hline $\mathrm{pH}+\mathrm{ECa}+\mathrm{MAP}+\mathrm{TN}^{-\mathrm{NO}_{3}}{ }^{-}$ & 0.475 & 0.001 \\
\hline
\end{tabular}

$r$ and $P$ represent the correlation coefficient and the significance value, respectively. MAT and MAP represent mean annual temperature and mean annual precipitation; $E K, E N a, E C a$, and $E M g$ represent soil exchangeable $\mathrm{K}^{+}, \mathrm{Na}^{+}, \mathrm{Ca}^{2+}$, and $\mathrm{Mg}^{2+}$ contents, respectively; TC, TN, TP, and AP represent soil total carbon, total nitrogen, total phosphorus and available phosphorus contents, respectively; $\mathrm{NH}_{4}^{+}$ and $\mathrm{NO}_{3}^{-}$represent soil extractable $\mathrm{NH}_{4}^{+}$and $\mathrm{NO}_{3}^{-}$levels; $\mathrm{MBC}$ represents soil microbial biomass carbon.

(Lauber et al., 2009) and the 26 black soils in northeastern China (Liu et al., 2014). They both found Acidobacteria was the most abundant phylum and Bacteroidetes was 11.2 and $5.6 \%$ as reported by Lauber et al. (2009) and Liu et al. (2014), respectively. Moreover, the relative abundance of Verrucomicrobia (8.68\%) and Planctomycetes (6.75\%) phyla in our study was much higher than results in Lauber et al. (2009) (0.9 and 0.09\%, respectively) and Liu et al. (2014) (3.22 and 4.85\%, respectively). Previous studies may have underestimated the abundance of Verrucomicrobia due to the bias of primers (Bergmann et al., 2011). However, using the same primers as this study, Fierer et al. (2012) found a huge variability in the relative abundance of the major bacterial taxa among different biomes including tropical forest, temperate forest, and boreal forest soils collected from different sites (for example, 5.22-40.29\% for Verrucomicrobia and $1.61-5.56 \%$ for Bacteroidetes). Our results agreed with their findings and suggested that at large spatial scales, the dominant bacterial groups may be quite different among different regions.

We further studied the controlling factors of the dominant bacterial groups and found different bacterial groups responded differently to soil properties and local climate (MAT and MAP) gradients (Table 2). For example, Alphaproteobacteria and Gammaproteobacteria were more abundant in southern tropical zone than in northern temperate zone while Verrucomicrobia, Gemmatimonadetes, and Armatimonadetes presented the opposite trend. MAT and MAP may have played an important role in influencing some bacterial taxa, especially for Verrucomicrobia and Armatimonadetes, which had no or weak relevance to soil properties but strong relationship with local climate (Table 2). A significant negative correlation was observed between MAP and the relative abundance of Verrucomicrobia in forest soils in this study (Table 2), while the opposite trend was found in grassland soils of the arid and semiarid areas in China (Wang et al., 2015). Therefore, the responses of Verrucomicrobia to climatic conditions were different between arid/semiarid areas and semi-humid/humid areas, and that the intermediate amount of precipitation (e.g., 400-500 mm MAP) was probably the most beneficial for Verrucomicrobia. In general, the relative abundance of most phyla was positively correlated to soil parameters such as $\mathrm{pH}$, exchangeable cations, $\mathrm{C}, \mathrm{N}, \mathrm{P}, \mathrm{NH}_{4}^{+}$and $\mathrm{NO}_{3}^{-}$(Table 2; Figure 2), which indicated that most bacterial taxa exhibited copiotrophic attributes and seemed to be favored by neutral $\mathrm{pH}$ and high carbon availability. Prior studies also found that most bacteria benefits from optimum living conditions (McCaig et al., 1999; Axelrood et al., 2002; Padmanabhan et al., 2003; Fierer et al., 2007). However, Actinobacteria, Alphaproteobacteria, Firmicutes and the dominant subgroups of Acidobacteria (GP1 to GP3) showed negative relationships with those soil parameters (Table 2, Supplementary Table S3; Figure 3, Supplementary Figures S1 and S2). Therefore, they possibly had oligotrophic lifestyle and were adapted to low-nutrient and low $\mathrm{pH}$ soils, which were consistent with previous reports (Fierer et al., 2007; Naether et al., 2012).

\section{Spatial Patterns of Bacterial Biogeographic Distribution}

We found the relationship between soil bacterial diversity and latitude was a parabola shape with the tipping point (maximum) at between $33.50^{\circ} \mathrm{N}$ and $40^{\circ} \mathrm{N}$ (Figure 4), which falls into the warm-temperate zone of China with MAT of about $7-9^{\circ} \mathrm{C}$ (Supplementary Table S1; Figure 4). The changes of animal and plant diversity with latitudinal gradients have been well documented and studied for centuries with the well-established conclusion that plants and animals generally exhibit an increase of diversity with decreasing latitude (Lomolino et al., 2006). However, whether microbial diversity also exhibits a latitudinal gradient has not reached a general conclusion. Some studies found that bacterial diversity increased or decreased with latitude (Buckley et al., 2003; Fuhrman et al., 2008; Liu et al., 2014), while other studies found no relationship between bacterial diversity 


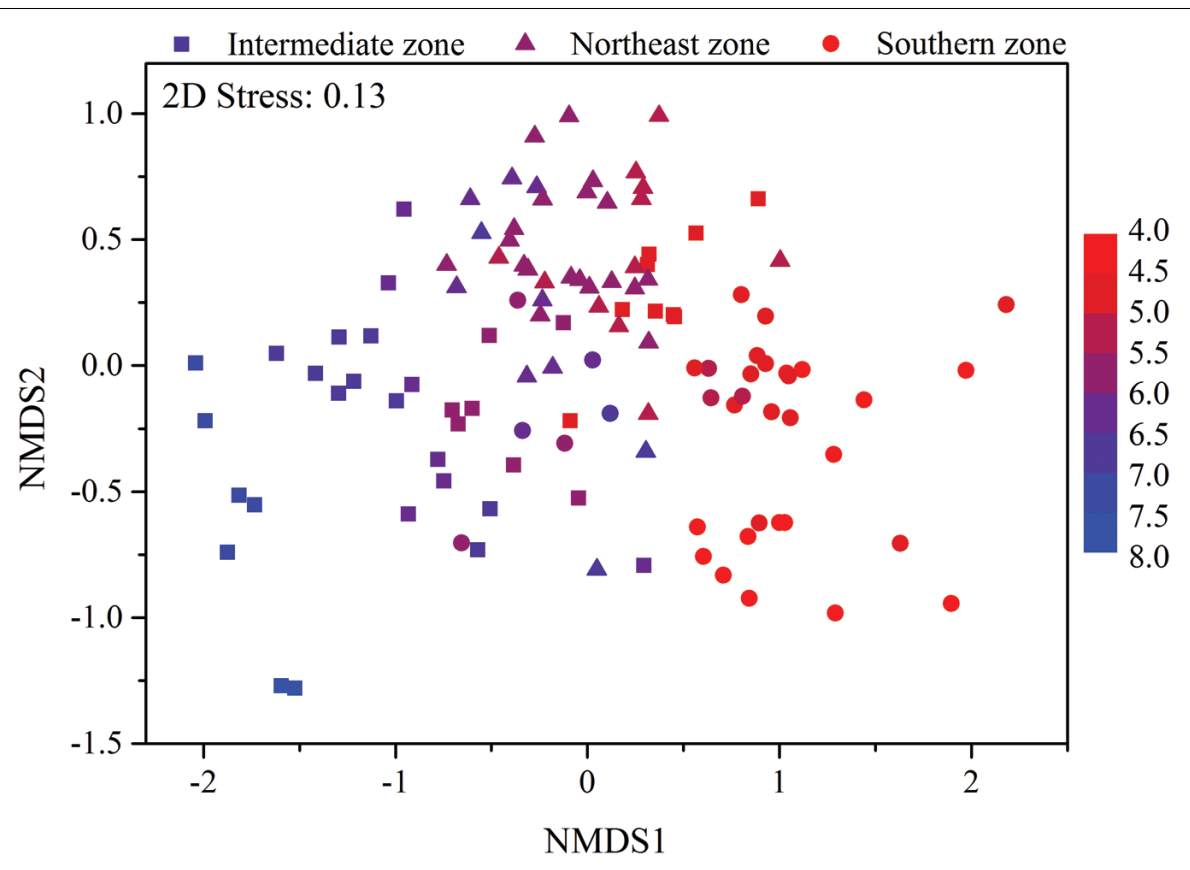

FIGURE 5 | Non-metric multidimensional scaling (NMDS) plot of bacterial community composition from 115 sites in typical Chinese forest soils. Sites are color coded according to the soil $\mathrm{pH}$ values. The filled circle represent sites in southern zone with latitude between $18.70^{\circ} \mathrm{N}$ and $29.65^{\circ} \mathrm{N}$, the filled triangles represent sites in northeast zone with latitude between $40.51^{\circ} \mathrm{N}$ and $51.53^{\circ} \mathrm{N}$ and the filled squares represent sites in intermediate zone with latitude between $31.30^{\circ} \mathrm{N}$ and $39.96^{\circ} \mathrm{N}$.

and latitude (Fierer and Jackson, 2006; Corby-Harris et al., 2007; Lauber et al., 2009; Chu et al., 2010). The latitudinal trend found in our study was based on the large scale data with a latitude range between $18.70^{\circ} \mathrm{N}$ and $51.53^{\circ} \mathrm{N}$. The parabola shaped relationship between bacterial diversity and latitude indicated that optimum conditions for highest bacterial diversity in our studied areas were located at the warm-temperate zone and bacteria did not show a simply latitudinal diversity gradient as previously reported (Buckley et al., 2003; Fuhrman et al., 2008; Liu et al., 2014). In the areas with higher bacterial diversity, most forests belong to the deciduous broad-leaved forest type, which have higher substrate availability (such as $\mathrm{C}$ or $\mathrm{N}$ sources) for bacterial growth compared to coniferous forest (Huang et al., 2004; Geng et al., 2009), or have a more comfortable soil physical environment for bacteria (Wallenstein et al., 2007). The near-neutral $\mathrm{pH}(6-7)$ and temperate climate conditions (Figure 4) may also contribute to the high bacterial diversity in this area.

According to the dissimilarity matrix in the whole bacterial community composition, all 115 soil samples in this study were clustered into two main groups (Figure 7), which were located in the low latitude zone $\left(18.70^{\circ} \mathrm{N}\right.$ to $\left.29.65^{\circ} \mathrm{N}\right)$ and the middle latitude zone $\left(31.30^{\circ} \mathrm{N}\right.$ to $52.53^{\circ} \mathrm{N}$ ) (Supplementary Table $\mathrm{S} 1$ ). Moreover, a significant correlation was observed between geographic distances and bacterial community dissimilarities (Figures 8A,B). These findings suggested that the soil bacterial communities in the Chinese forest soils zone were distributed geographically. It is clear that soil bacterial communities in southern forests are distinct from those in northern forests and $30^{\circ} \mathrm{N}$ could be coarsely considered as the dividing line between them. However, some soil samples in tropical or subtropical forests (for examples JFL07, JFL08, JFL09, HNZZ01 and HNZZ03) were clustered into group A (mainly consist of northern temperate and boreal forest soils); while some bacterial community structure in temperate forest soils (BSLHJL and QL03) were more similar to that in southern forest soils (group I). This result suggested that soil properties and climatic factors (Figures $\mathbf{6}$ and $\mathbf{8 C , D}$ ) also play a very important role in determining bacterial community composition.

\section{Determinant Factors of the Biogeographic Distribution of Soil Bacteria}

The variation of soil bacterial phylotype and phylogenetic diversity along latitude gradients was similar to that along soil $\mathrm{pH}, \mathrm{ECa}^{2+}, \mathrm{EMg}^{2+}$ and $\mathrm{TC}$ gradients (Figure 4; Supplementary Figure S5). Therefore, these soil properties and climatic conditions (MAT and MAP) together determined the biogeographic distribution of soil bacteria in our studied areas although these parameters were inter-correlated with each other (Table 1). Multiple variable analysis suggested that soil $\mathrm{pH}$ was the most important determinant of soil bacterial community structure (Figures 5 and 6; Supplementary Figure S6), which has been broadly documented in soils from a broad range of ecosystems (Fierer and Jackson, 2006; Baker et al., 2009; Liu et al., 2014). In fact, the cluster analysis results which divided bacterial 
A

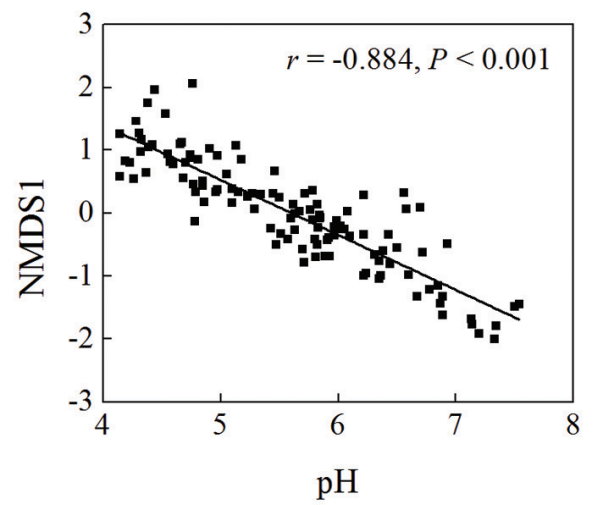

C

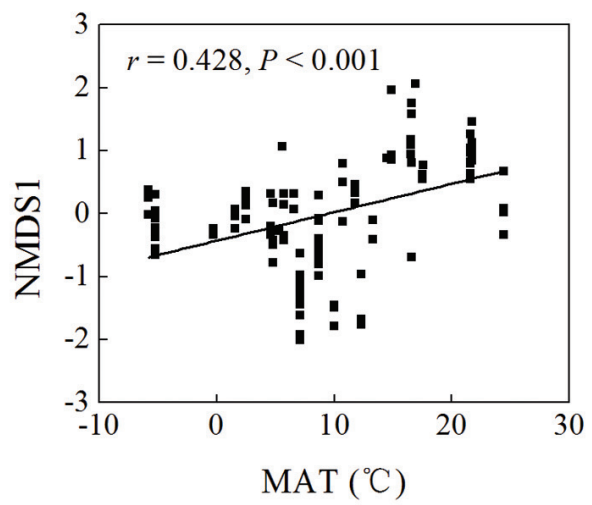

$\mathbf{E}$

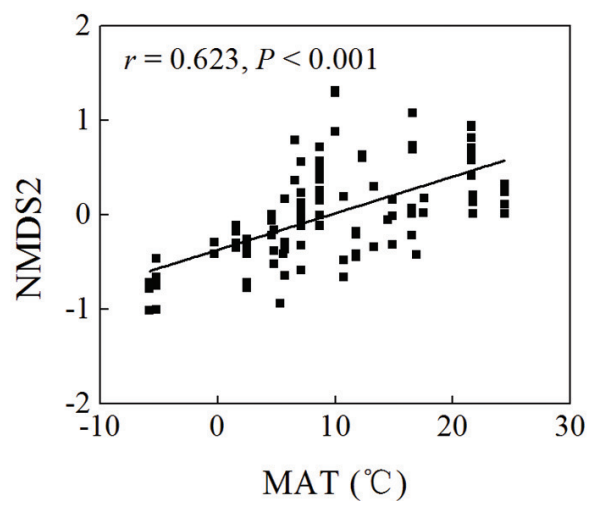

B

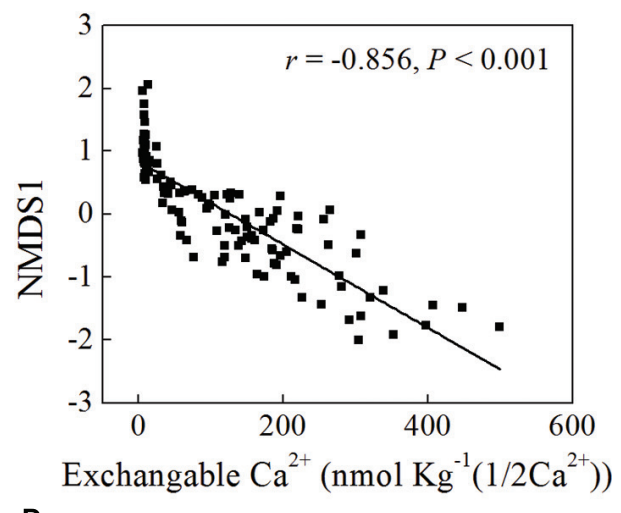

D

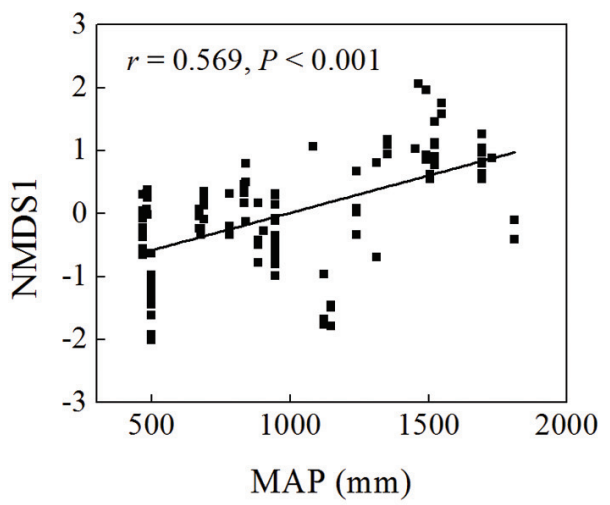

$\mathbf{F}$

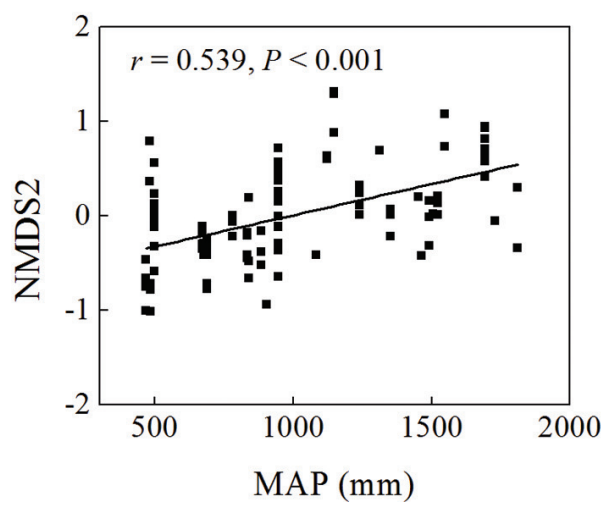

FIGURE 6 | Linear regression between non-metric multidimensional scaling (NMDS) scores (NMDS1 or NMDS2) and soil pH (A), exchangeable Ca ${ }^{2+}$ content (B), and MAT (C,E) and MAP (D,F) of sampling sites.

composition into southern (Group I) and northern forest (Group II) groups (Figure 7) was also related to changes of soil $\mathrm{pH}$ because most soils (28 out of 32 samples) from Group I were acidic with $\mathrm{pH}<5$, while the soils classified into group II mainly (74 out of 83 samples) had $\mathrm{pH}>5$ (Figure 5, Supplementary Table S1). Our results (Figure 4) agreed with previous findings that acidic soils usually showed lower phylogenetic diversity than neutral soils (Fierer and Jackson, 2006; Lauber et al., 2009; Chu et al., 2010) and were mostly dominated by particular taxa (Griffiths et al., 2011). Therefore, soil $\mathrm{pH}=5$ probably can be used as a dividing line between northern and southern China regarding soil bacterial community composition and also a threshold below which soil bacterial diversity may decline and soil bacterial community structure may change significantly.

It is noteworthy that some soil exchangeable cations $\left(\mathrm{Ca}^{2+}\right.$, $\mathrm{Mg}^{2+}, \mathrm{K}^{+}$) were also correlated with soil bacterial composition and diversity and some taxonomic groups (Table 3, Figures 3 and 4; Supplementary Figure S2). Soil pH strongly influenced these cations (Table 1), which agreed with previous findings 


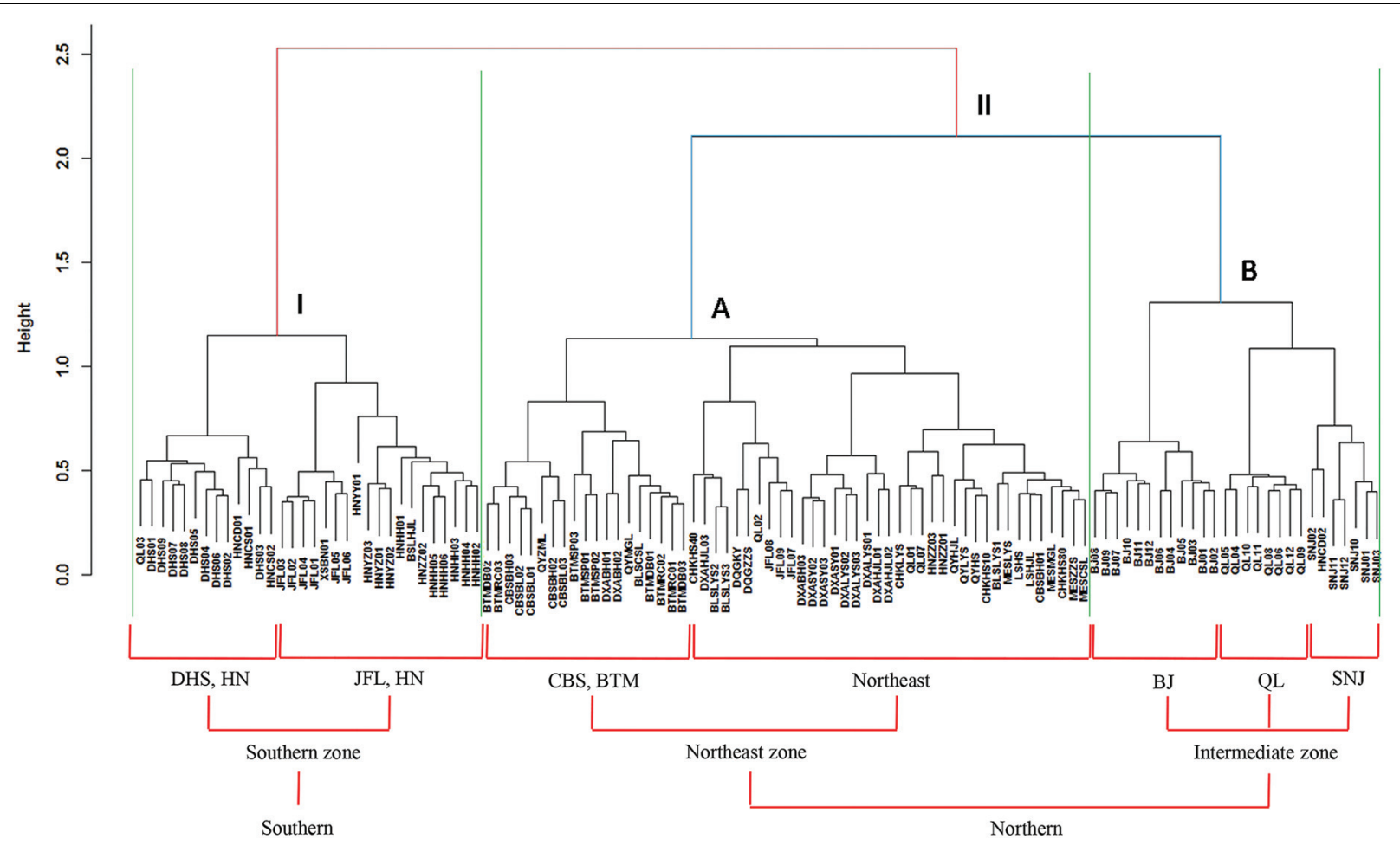

FIGURE 7 | Cluster analysis of bacterial communities based on "Bray-Curtis" dissimilarity matrix. The symbols located at the ends of the cluster branch represented all the 115 soil samples and their detailed information are listed in Supplementary Table S1. All the 115 soil samples were clustered into two main groups (I and II) which were roughly corresponding to southern and northern forest soils, respectively. Moreover, the group II was coarsely divided into two subgroups (A and B) which were mainly from northeast zone forest soils and intermediate zone forest soils, respectively.

conducted in tropical soils (Sanchez, 1977; Fearnside, 1984) and ferrosol soils (Lacey and Wilson, 2001). Therefore, it is understandable that the effects of these cations on microbial diversity were similar to the effects of soil $\mathrm{pH}$. Likewise, the threshold of soil $\mathrm{ECa}^{2+}$ at about $32 \mathrm{mmol} \mathrm{kg}^{-1}$ can also be used for partitioning bacterial community structures into group I (31 in 32 samples with $\mathrm{ECa}^{2+} \mathrm{s}<32 \mathrm{mmol} \mathrm{kg}^{-1}$ ) and group II (82 in 83 samples with $\mathrm{ECa}^{2+} \mathrm{s}>32 \mathrm{mmol} \mathrm{kg}^{-1}$ ) (Supplementary Table $\mathrm{S} 1$ ), suggesting that soil $\mathrm{ECa}^{2+}$ may be another suitable marker for cluster-dividing of soil bacterial community composition besides soil $\mathrm{pH}$.

We found environmental factors played a more important role in driving bacterial community pattern than geographic distance (explained 21.11 and $15.88 \%$ of the variation in bacterial community structure, respectively) at the large spatial scale of this study (Figure 9). This result was similar to the results obtained at a smaller scale in the black soils of northeast China (Liu et al., 2014), but different from a study conducted along a transect of arid and semi-arid grasslands in northern China, which showed geographic distance (36.02\%) explained more of the variation in bacterial community structure than environmental variables (24.06\%) (Wang et al., 2015). This was probably because the latter study was conducted along a latitudinal transect and the variations of climatic conditions and geographic distances were highly constrained. In addition, there was a significant correlation between geographic and environmental distance with a weak strength ('Mantel test', $r=0.16$ for pearson's rank correlation and $r=0.36$ for spearman's rank correlation, respectively, $p=0.001$, data not shown) across sites in this study, and this indicates that variation in bacterial community composition may be associated with both geographic distance and environmental dissimilarity between sites.

\section{CONCLUSION}

The soil bacterial phylogenetic diversity of typical eastern Chinese forests showed a parabola shape along latitude and the maximum diversity appeared at latitudes between $33.50^{\circ} \mathrm{N}$ and $40^{\circ} \mathrm{N}$, an area characterized by warm-temperate zones and moderate temperature, neutral soil $\mathrm{pH}$ and high substrate availability (soil $\mathrm{C}$ and $\mathrm{N}$ ) from dominant deciduous broadleaved forests. The dissimilarity matrix results showed that the latitude of $30^{\circ} \mathrm{N}$ was the dividing line in bacterial community composition between southern and northern forests. Soil properties and climate conditions (MAT and MAP) greatly accounted for the differences in the soil bacterial structure among examined forests. Soil $\mathrm{pH}$ was the most important determinant while soil exchangeable cations, especially $\mathrm{Ca}^{2+}$, and some other soil variables also showed impacts on the composition and diversity of the soil bacterial community. Soil $\mathrm{pH}=5$ or $\mathrm{ECa}^{2+}=32 \mathrm{mmol} \mathrm{kg}{ }^{-1}$ may be used as indicators 
A

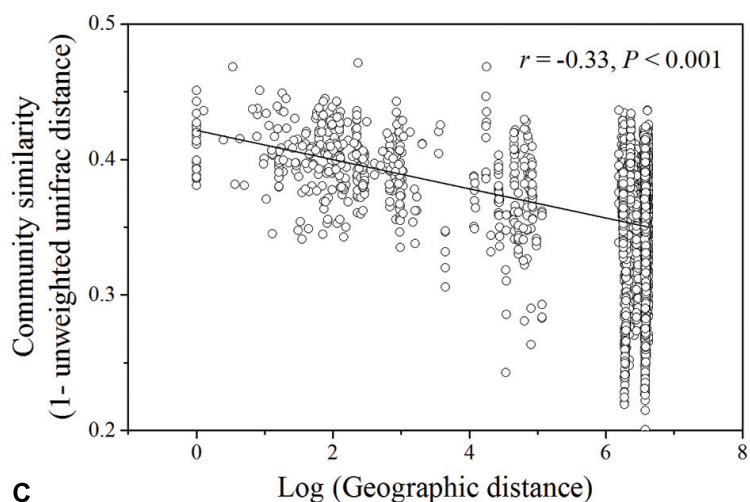

C

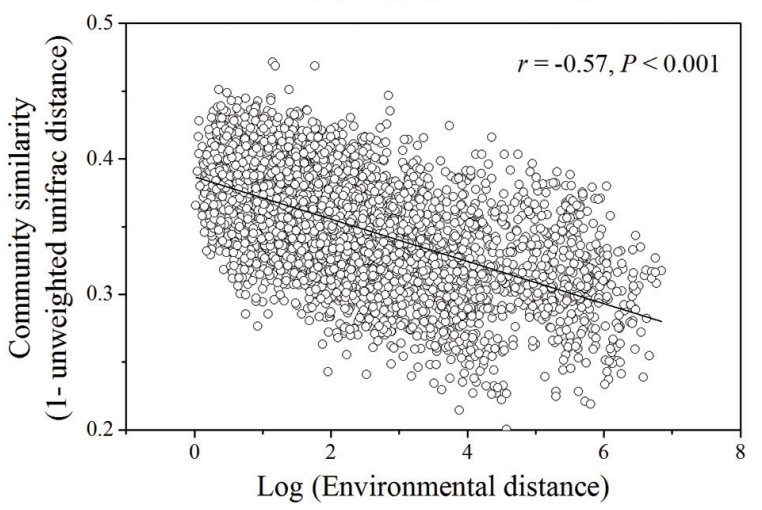

B
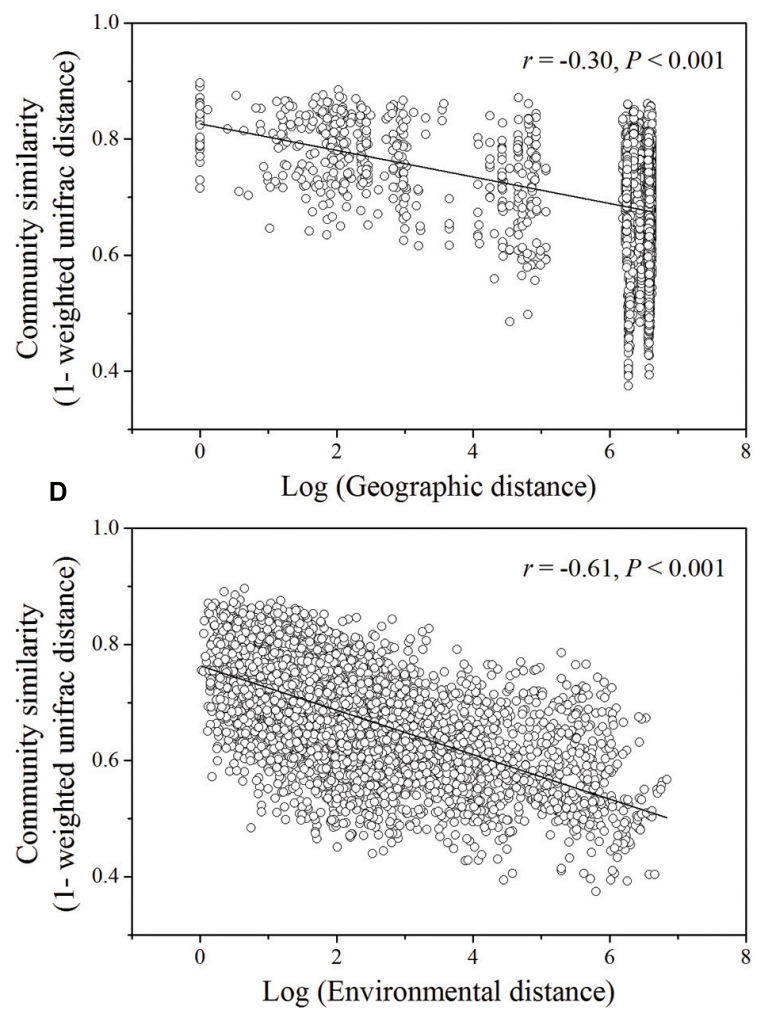

FIGURE 8 | Relationships between log of geographic distance (A,B) or environmental distance (C,D) and bacterial community similarity. The significant vectors formed during PCNM analysis of geographic coordinates of sampling sties were used to construct geographic distance matrix. The environmental variables $\left(\mathrm{pH}, \mathrm{ECa}, \mathrm{NH}_{4}^{+}\right)$used to estimate environmental distance were selected by BioEnv procedure. Bacterial community similarity was estimated by pairwise Unifrac distance (unweighted or weighted) in community composition.

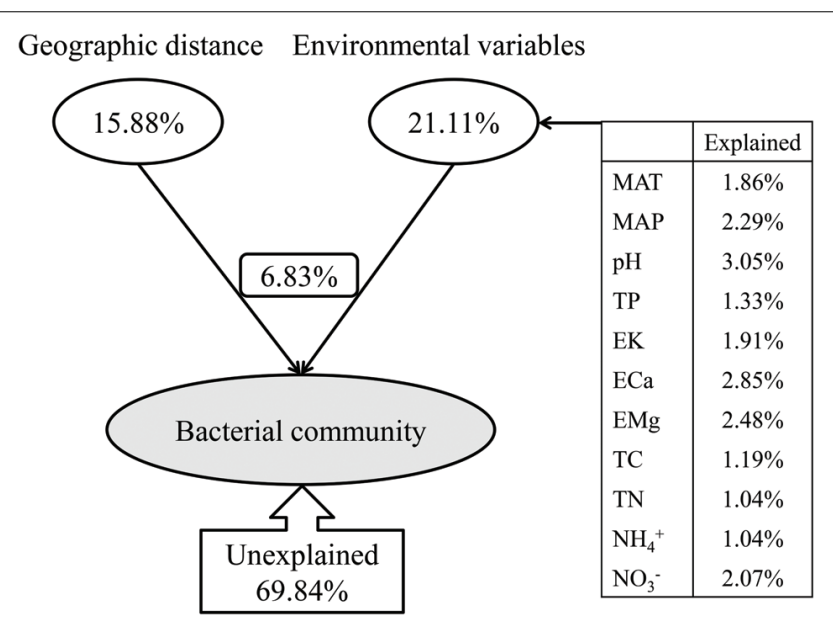

FIGURE 9 | Variation partition analysis of the effects of geographic distance and environmental variables on the bacterial community. The environmental variables show different contributions to the variation of the bacteria community. MAT and MAP represent mean annual temperature and mean annual precipitation; TP represent soil total phosphorus contents; EK, ECa and EMg represent soil exchangeable $\mathrm{K}^{+}, \mathrm{Ca}^{2+}$ and $\mathrm{Mg}^{2+}$ contents, respectively; $\mathrm{NH}_{4}^{+}$and $\mathrm{NO}_{3}^{-}$represent soil extractable $\mathrm{NH}_{4}^{+}$and $\mathrm{NO}_{3}^{-}$levels; $\mathrm{MBC}$ represents soil microbial biomass carbon. for differentiating southern acidic forest soils from northern temperate forest soils in bacterial community composition in China. The edaphic variables and environmental factors played a more important role than geographic dispersal limitation in determining the bacterial community structure in studied soils. This work for the first time identifies factors that govern the biogeography of bacteria in forest soils across China. Further research aimed at other non-forest soils are needed to comprehensively understand the biogeography of bacteria in soils from China.

\section{AUTHOR CONTRIBUTIONS}

Conceived and designed experiments: EB, QW, and ZX. Performed the experiments: ZX, QW, DG, PJ, and JW. Analyzed the data: ZX, EB, and JZ. Wrote the paper: ZX and EB. All authors read and approved the final manuscript.

\section{FUNDING}

This study was supported by the Major State Basic Research Development Program of China (973 Program, 2014CB954400), 
the Strategic Priority Research Program of the Chinese Academy of Sciences (XDB15010301) and the National Natural Science Foundation of China (31400427).

\section{ACKNOWLEDGMENTS}

We are grateful to Longchi Chen, Bing Fan, Yang Cui, Shunzhong Wang, and Hongtu Xie for their help with field sampling and sample pre-treatment. We are also very

\section{REFERENCES}

Allen, A. P., Brown, J. H., and Gillooly, J. F. (2002). Global biodiversity, biochemical kinetics, and the energetic-equivalence rule. Science 297, 1545-1548. doi: $10.1126 /$ science. 1072380

Axelrood, P. E., Chow, M. L., Radomski, C. C., McDermott, J. M., and Davies, J. (2002). Molecular characterization of bacterial diversity from British Columbia forest soils subjected to disturbance. Can. J. Microbiol. 48, 655-674. doi: 10.1139/w02-075

Baker, K. L., Langenheder, S., Nicol, G. W., Ricketts, D., Killham, K., Campbell, C. D., et al. (2009). Environmental and spatial characterisation of bacterial community composition in soil to inform sampling strategies. Soil Biol. Biochem. 41, 2292-2298. doi: 10.1016/j.soilbio.2009.08.010

Bergmann, G. T., Bates, S. T., Eilers, K. G., Lauber, C. L., Caporaso, J. G., Walters, W. A., et al. (2011). The under-recognized dominance of Verrucomicrobia in soil bacterial communities. Soil Biol. Biochem. 43, 1450-1455. doi: 10.1016/j.soilbio.2011.03.012

Borcard, D., and Legendre, P. (2002). All-scale spatial analysis of ecological data by means of principal coordinates of neighbour matrices. Ecol. Modell. 153, 51-68. doi: 10.1016/S0304-3800(01)00501-4

Broughton, L., and Gross, K. (2000). Patterns of diversity in plant and soil microbial communities along a productivity gradient in a Michigan old-field. Oecologia 125, 420-427. doi: 10.1007/s004420000456

Brussaard, L. (1997). Biodiversity and ecosystem functioning in soil. Ambio 26, $563-570$.

Buckley, H. L., Miller, T. E., Ellison, A. M., and Gotelli, N. J. (2003). Reverse latitudinal trends in species richness of pitcher-plant food webs. Ecol. Lett. 6, 825-829. doi: 10.1046/j.1461-0248.2003.00504.x

Caporaso, J. G., Kuczynski, J., Stombaugh, J., Bittinger, K., Bushman, F. D., Costello, E. K., et al. (2010). QIIME allows analysis of highthroughput community sequencing data. Nat. Methods 7, 335-336. doi: 10.1038/nmeth.f.303

Cho, J.-C., and Tiedje, J. M. (2000). Biogeography and degree of endemicity of fluorescent Pseudomonas strains in soil. Appl. Environ. Microbiol. 66, 54485456. doi: 10.1128/AEM.66.12.5448-5456.2000

Chu, H., Fierer, N., Lauber, C. L., Caporaso, J., Knight, R., and Grogan, P. (2010). Soil bacterial diversity in the Arctic is not fundamentally different from that found in other biomes. Environ. Microbiol. 12, 2998-3006. doi: 10.1111/j.14622920.2010.02277.x

Clarke, K. R., and Ainsworth, M. (1993). A method of linking multivariate community structure to environmental variables. Mar. Ecol. Prog. Ser. 92, 205-219. doi: 10.3354/meps092205

Corby-Harris, V., Pontaroli, A. C., Shimkets, L. J., Bennetzen, J. L., Habel, K. E., and Promislow, D. E. L. (2007). Geographical distribution and diversity of bacteria associated with natural populations of Drosophila melanogaster. Appl. Environ. Microbiol. 73, 3470-3479. doi: 10.1128/aem.02120-06

Crump, B. C., Hopkinson, C. S., Sogin, M. L., and Hobbie, J. E. (2004). Microbial biogeography along an estuarine salinity gradient: combined influences of bacterial growth and residence time. Appl. Environ. Microbiol. 70, 1494-1505. doi: 10.1128/AEM.70.3.1494-1505.2004

Davis, J. P., Youssef, N. H., and Elshahed, M. S. (2009). Assessment of the diversity, abundance, and ecological distribution of members of candidate division SR1 reveals a high level of phylogenetic diversity but limited morphotypic diversity. Appl. Environ. Microbiol. 75, 4139-4148. doi: 10.1128/AEM.00137-09 grateful to Xiaoxu Bai for her help with data analysis of high throughput sequencing and multivariate statistical analysis.

\section{SUPPLEMENTARY MATERIAL}

The Supplementary Material for this article can be found online at: http://journal.frontiersin.org/article/10.3389/fmicb. 2016.01106

Dequiedt, S., Thioulouse, J., Jolivet, C., Saby, N., Lelievre, M., Maron, P. A., et al. (2009). Biogeographical patterns of soil bacterial communities. Environ. Microbiol. Rep. 1, 251-255. doi: 10.1111/j.1758-2229.2009.00040.x

DeSantis, T., Hugenholtz, P., Keller, K., Brodie, E., Larsen, N., Piceno, Y., et al. (2006). NAST: a multiple sequence alignment server for comparative analysis of 16S rRNA genes. Nucleic Acids Res. 34, W394-W399. doi: 10.1093/nar/gkl244

Fearnside, P. M. (1984). Initial soil quality conditions on the transamazon highway of Brazil and their simulation in models for estimating human carrying capacity. Trop. Ecol. 25, 1-21.

Fierer, N., Bradford, M. A., and Jackson, R. B. (2007). Toward an ecological classification of soil bacteria. Ecology 88, 1354-1364. doi: 10.1890/05-1839

Fierer, N., Leff, J. W., Adams, B. J., Nielsen, U. N., Bates, S. T., Lauber, C. L., et al. (2012). Cross-biome metagenomic analyses of soil microbial communities and their functional attributes. Proc. Natl. Acad. Sci. U.S.A. 109, 21390-21395. doi: 10.1073/pnas.1215210110

Fierer, N., and Jackson, R. B. (2006). The diversity and biogeography of soil bacterial communities. Proc. Natl. Acad. Sci. U.S.A. 103, 626-631. doi: 10.1073/pnas.0507535103

Fuhrman, J. A., Steele, J. A., Hewson, I., Schwalbach, M. S., Brown, M. V., Green, J. L., et al. (2008). A latitudinal diversity gradient in planktonic marine bacteria. Proc. Natl. Acad. Sci. U.S.A. 105, 7774-7778. doi: 10.1073/pnas.0803070105

Ganderton, P., and Coker, P. (2005). Environmental Biogeography. Essex: Pearson Education.

Garbeva, P., Van Veen, J., and Van Elsas, J. (2004). Microbial diversity in soil: selection of microbial populations by plant and soil type and implications for disease suppressiveness. Annu. Rev. Phytopathol. 42, 243-270. doi: 10.1146/annurev.phyto.42.012604.135455

Gaston, K. J. (2000). Global patterns in biodiversity. Nature 405, 220-227. doi: $10.1038 / 35012228$

Ge, Y., He, J.-Z., Zhu, Y.-G., Zhang, J.-B., Xu, Z., Zhang, L.-M., et al. (2008). Differences in soil bacterial diversity: driven by contemporary disturbances or historical contingencies? ISME J. 2, 254-264. doi: 10.1038/ismej.2008.2

Geng, Y.-Q., Yu, X.-X., Yue, Y.-J., Li, J.-H., and Zhang, G.-Z. (2009). Active organic carbon pool of coniferous and broad-leaved forest soils in the mountainous areas of Beijing. For. Stud. China 11, 225-230. doi: 10.1007/s11632-0090035-0

Green, J. L., Bohannan, B. J., and Whitaker, R. J. (2008). Microbial biogeography: from taxonomy to traits. Science 320, 1039-1043. doi: 10.1126/science.1153475

Griffiths, R. I., Thomson, B. C., James, P., Bell, T., Bailey, M., and Whiteley, A. S. (2011). The bacterial biogeography of British soils. Environ. Microbiol. 13, 1642-1654. doi: 10.1111/j.1462-2920.2011.02480.x

Huang, Y., Wang, S., Feng, Z., Ouyang, Z., Wang, X., and Feng, Z. (2004). Changes in soil quality due to introduction of broad-leaf trees into clear-felled Chinese fir forest in the mid-subtropics of China. Soil Use Manag. 20, 418-425. doi: 10.1079/SUM2004274

Jenkins, S. N., Waite, I. S., Blackburn, A., Husband, R., Rushton, S. P., Manning, D. C., et al. (2009). Actinobacterial community dynamics in long term managed grasslands. Antonie Van Leeuwenhoek 95, 319-334. doi: 10.1007/s10482-0099317-8

Joergensen, R. G. (1996). The fumigation-extraction method to estimate soil microbial biomass: calibration of the kEC value. Soil Biol. Biochem. 28, 25-31. doi: 10.1016/0038-0717(95)00102-6

Jones, R. T., Robeson, M. S., Lauber, C. L., Hamady, M., Knight, R., and Fierer, N. (2009). A comprehensive survey of soil acidobacterial diversity 
using pyrosequencing and clone library analyses. ISME J. 3, 442-453. doi: 10.1038/ismej.2008.127

Kuo, S. (1996). "Phosphorus," in Methods of Soil Analysis. Part 3 - Chemical Methods, eds D. L. Sparks, A. L. Page, P. A. Helmke, R. H. Loeppert, P. N. Soltanpour, M. A. Tabatabai, et al. (Madison, WI: Soil Science Society of America and American Society of Agronomy), 869-919.

Lacey, M., and Wilson, C. (2001). Relationship of common scab incidence of potatoes grown in Tasmanian ferrosol soils with $\mathrm{pH}$, exchangeable cations and other chemical properties of those soils. J. Phytopathol. 149, 679-683. doi: 10.1046/j.1439-0434.2001.00693.x

Lauber, C. L., Hamady, M., Knight, R., and Fierer, N. (2009). Pyrosequencingbased assessment of soil $\mathrm{pH}$ as a predictor of soil bacterial community structure at the continental scale. Appl. Environ. Microbiol. 75, 5111-5120. doi: 10.1128/AEM.00335-09

Legendre, P., and Legendre, L. (2012). Numerical Ecology, 3rd English Edn. Amsterdam: Elsevier.

Legendre, P., Oksanen, J., and ter Braak, C. J. F. (2011). Testing the significance of canonical axes in redundancy analysis. Methods Ecol. Evol. 2, 269-277. doi: 10.1111/j.2041-210X.2010.00078.x

Levin, S. A. (1992). The problem of pattern and scale in ecology: the Robert H. MacArthur award lecture. Ecology 73, 1943-1967. doi: 10.2307/1941447

Liu, J., Sui, Y., Yu, Z., Shi, Y., Chu, H., Jin, J., et al. (2014). High throughput sequencing analysis of biogeographical distribution of bacterial communities in the black soils of northeast China. Soil Biol. Biochem. 70, 113-122. doi: 10.1016/j.soilbio.2013.12.014

Liu, Z., Fu, B., Zheng, X., and Liu, G. (2010). Plant biomass, soil water content and soil $\mathrm{N}$ : $\mathrm{P}$ ratio regulating soil microbial functional diversity in a temperate steppe: a regional scale study. Soil Biol. Biochem. 42, 445-450. doi: 10.1016/j.soilbio.2009.11.027

Lomolino, M. V., Riddle, B. R., and Brown, J. H. (2006). Biogeography. Sunderland, MA: Sinauer Associates.

Lozupone, C., and Knight, R. (2005). UniFrac: a new phylogenetic method for comparing microbial communities. Appl. Environ. Microbiol. 71, 8228-8235. doi: 10.1128/AEM.71.12.8228-8235.2005

Lozupone, C. A., and Knight, R. (2007). Global patterns in bacterial diversity. Proc. Natl. Acad. Sci. U.S.A. 104, 11436-11440. doi: 10.1073/pnas.0611525104

Maestre, F. T., Delgado-Baquerizo, M., Jeffries, T. C., Eldridge, D. J., Ochoa, V., Gozalo, B., et al. (2015). Increasing aridity reduces soil microbial diversity and abundance in global drylands. Proc. Natl. Acad. Sci. U.S.A. 112, 15684-15689. doi: $10.1073 /$ pnas. 1516684112

Magoč, T., and Salzberg, S. L. (2011). FLASH: fast length adjustment of short reads to improve genome assemblies. Bioinformatics 27, 2957-2963. doi: 10.1093/bioinformatics/btr507

Martiny, J. B. H., Bohannan, B. J., Brown, J. H., Colwell, R. K., Fuhrman, J. A., Green, J. L., et al. (2006). Microbial biogeography: putting microorganisms on the map. Nat. Rev. Microbiol. 4, 102-112. doi: 10.1038/nrmicro1341

McCaig, A. E., Glover, L. A., and Prosser, J. I. (1999). Molecular analysis of bacterial community structure and diversity in unimproved and improved upland grass pastures. Appl. Environ. Microbiol. 65, 1721-1730.

Minchin, P. R. (1987). An evaluation of relative robustness of techniques for ecological ordinations. Vegetatio 69, 89-107. doi: 10.1007/BF00038690

Murtagh, F. (1985). Multidimensional Clustering Algorithms. COMPSTAT Lectures 4. Wuerzburg: Physica-Verlag.

Naether, A., Foesel, B. U., Naegele, V., Wüst, P. K., Weinert, J., Bonkowski, M., et al. (2012). Environmental factors affect acidobacterial communities below the subgroup level in grassland and forest soils. Appl. Environ. Microbiol. 78, 7398-7406. doi: 10.1128/AEM.01325-12

Nicol, G. W., Leininger, S., Schleper, C., and Prosser, J. I. (2008). The influence of soil $\mathrm{pH}$ on the diversity, abundance and transcriptional activity of ammonia oxidizing archaea and bacteria. Environ. Microbiol. 10, 2966-2978. doi: 10.1111/j.1462-2920.2008.01701.x
Oksanen, J., Blanchet, F. G., Kindt, R., Legendre, P., Minchin, P. R., O’Hara, R. B., et al. (2016). vegan: Community Ecology Package. R Package version 2.3-5. Available at: https://CRAN.R-project.org/package=vegan

Padmanabhan, P., Padmanabhan, S., DeRito, C., Gray, A., Gannon, D., Snape, J., et al. (2003). Respiration of 13C-labeled substrates added to soil in the field and subsequent 16S rRNA gene analysis of 13C-labeled soil DNA. Appl. Environ. Microbiol. 69, 1614-1622. doi: 10.1128/AEM.69.3.1614-1622.2003

Pasternak, Z., Al-Ashhab, A., Gatica, J., Gafny, R., Avraham, S., Minz, D., et al. (2013). Spatial and temporal biogeography of soil microbial communities in arid and semiarid regions. PLOS ONE 8:e69705. doi: 10.1371/journal.pone.0069705

R Development Core Team (2006). R: A language and environment for statistical computing. R 21. Vienna: Foundation for Statistical Computing.

Ramette, A., and Tiedje, J. M. (2007). Biogeography: an emerging cornerstone for understanding prokaryotic diversity, ecology, and evolution. Microb. Ecol. 53, 197-207. doi: 10.1007/s00248-005-5010-2

Sanchez, P. A. (1977). Properties and management of soils in the tropics. Soil Sci. 124:187. doi: 10.1097/00010694-197709000-00012

Shaw, A. K., Halpern, A. L., Beeson, K., Tran, B., Venter, J. C., and Martiny, J. B. H. (2008). It's all relative: ranking the diversity of aquatic bacterial communities. Environ. Microbiol. 10, 2200-2210. doi: 10.1111/j.1462-2920.2008.01626.x

Stephan, A., Meyer, A. H., and Schmid, B. (2000). Plant diversity affects culturable soil bacteria in experimental grassland communities. J. Ecol. 88, 988-998. doi: 10.1046/j.1365-2745.2000.00510.x

Thomas, G. W. (1982). "Exchangeable cations," in Methods of Soil Analysis. Part 2. Chemical and Microbiological Properties, 2nd Edn, eds A. L. Page, R. H. Miller, and D. R. Keeney (Madison, WI: ASA and SSSA), 159-164.

Vance, E. D., Brookes, P. C., and Jenkinson, D. S. (1987). An extraction method for measuring soil microbial biomass C. Soil Biol. Biochem. 19, 703-707. doi: 10.1016/0038-0717(87)90052-6

Wallenstein, M. D., McMahon, S., and Schimel, J. (2007). Bacterial and fungal community structure in Arctic tundra tussock and shrub soils. FEMS Microbiol. Ecol. 59, 428-435. doi: 10.1111/j.1574-6941.2006.00260.x

Wang, Q., Garrity, G. M., Tiedje, J. M., and Cole, J. R. (2007). Naive Bayesian classifier for rapid assignment of rRNA sequences into the new bacterial taxonomy. Appl. Environ. Microbiol. 73, 5261-5267. doi: 10.1128/AEM. 00062-07

Wang, X., Van Nostrand, J. D., Deng, Y., Lü, X., Wang, C., Zhou, J., et al (2015). Scale-dependent effects of climate and geographic distance on bacterial diversity patterns across northern China's grasslands. FEMS Microbiol. Ecol. 91:fiv133. doi: 10.1093/femsec/fiv133

Wardle, D. A., Bardgett, R. D., Klironomos, J. N., Setälä, H., Van Der Putten, W. H., and Wall, D. H. (2004). Ecological linkages between aboveground and belowground biota. Science 304, 1629-1633. doi: 10.1126/science.1094875

Yergeau, E., Newsham, K. K., Pearce, D. A., and Kowalchuk, G. A. (2007). Patterns of bacterial diversity across a range of Antarctic terrestrial habitats. Environ. Microbiol. 9, 2670-2682. doi: 10.1111/j.1462-2920.2007.01379.x

Zhou, J., Xia, B., Treves, D. S., Wu, L.-Y., Marsh, T. L., O’Neill, R. V., et al. (2002). Spatial and resource factors influencing high microbial diversity in soil. Appl. Environ. Microbiol. 68, 326-334. doi: 10.1128/AEM.68.1.326-334.2002

Conflict of Interest Statement: The authors declare that the research was conducted in the absence of any commercial or financial relationships that could be construed as a potential conflict of interest.

Copyright (c) 2016 Xia, Bai, Wang, Gao, Zhou, Jiang and Wu. This is an open-access article distributed under the terms of the Creative Commons Attribution License (CC BY). The use, distribution or reproduction in other forums is permitted, provided the original author(s) or licensor are credited and that the original publication in this journal is cited, in accordance with accepted academic practice. No use, distribution or reproduction is permitted which does not comply with these terms. 